\title{
A keystone species, European aspen (Populus tremula L.), in boreal forests : Ecological role, knowledge needs and mapping using remote sensing
}

\section{Kivinen, Sonja}

2020-04

Kivinen , S , Koivisto , E , Keski-Saari , S , Poikolainen , L, Tanhuanpää , T , Kuzmin , A , Viinikka , A , Heikkinen, R K , Virkkala , R, Vihervaara , P \& Kumpula , T 2020 , ' A keystone species, European aspen (Populus tremula L.), in boreal forests : Ecological role, knowledge needs and mapping using remote sensing ', Forest Ecology and Management , vol. 462 , 118008 . https://doi.org/10.1016/j.foreco.2020.118008

http://hdl.handle.net/10138/340973

https://doi.org/10.1016/j.foreco.2020.118008

CC BY-NC-ND

acceptedVersion

Downloaded from Helda, University of Helsinki institutional repository.

This is an electronic reprint of the original article.

This reprint may differ from the original in pagination and typographic detail.

Please cite the original version. 
1 A keystone species, European aspen (Populus tremula $L$.), in boreal forests:

2 ecological role, knowledge needs and mapping using remote sensing

3

4

5 Sonja Kivinen ${ }^{1,2^{*}}$, Elina Koivisto ${ }^{3}$, Sarita Keski-Saari ${ }^{1,4}$, Laura Poikolainen ${ }^{1}$, Topi Tanhuanpää ${ }^{1,5}$,

6 Anton Kuzmin ${ }^{1}$, Arto Viinikka ${ }^{2}$, Risto K. Heikkinen ${ }^{2}$, Juha Pykälä ${ }^{2}$, Raimo Virkkala ${ }^{2}$, Petteri

$7 \quad$ Vihervaara $^{2} \&$ Timo Kumpula ${ }^{1}$

8

9

10

11

12

13

14

15

16

17

18

19

20

21

22

23

24

25

${ }^{1}$ Department of Geographical and Historical Studies, University of Eastern Finland, P.O. Box 111, FI-80101 Joensuu, Finland.

${ }^{2}$ Finnish Environment Institute, Latokartanonkaari 11, FI-00790 Helsinki, Finland

${ }^{3}$ University of Turku, Department of Biology, FI-20014 Turun yliopisto, Finland

${ }^{4}$ Department of Environmental and Biological Sciences, University of Eastern Finland, P.O. Box

111, FI-80101 Joensuu, Finland

${ }^{5}$ Department of Forest Sciences, University of Helsinki, FI-00014, Helsinki, Finland 6

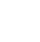

9

0




\section{Abstract}

27 European aspen (Populus tremula L.) is a keystone species in boreal forests that are dominated by coniferous tree species. Both living and dead aspen trees contribute significantly to the species diversity of forest landscapes. Thus, spatial and temporal continuity of aspen is a prerequisite for the long-term persistence of viable populations of numerous aspen-associated species. In this review, we collate existing knowledge on the ecological role of European aspen, assess the knowledge needs for aspen occurrence patterns and dynamics in boreal forests and discuss the potential of different remote sensing techniques in mapping aspen at various spatiotemporal scales. The role of aspen as a key ecological feature has received significant attention, and studies have recognised the negative effects of modern forest management methods and heavy browsing on aspen occurrence and regeneration. However, the spatial knowledge of occurrence, abundance and temporal dynamics of aspen is scarce and incomprehensive. The remote sensing studies reviewed here highlight particularly the potential of three-dimensional data derived from airborne laser scanning or photogrammetric point clouds and airborne imaging spectroscopy in mapping European aspen, quaking aspen (Populus tremuloides Michx.) and other Populus species. In addition to tree species discrimination, these methods can provide information on biophysical, biochemical properties and even genetic diversity of aspen trees. Major obstacles in aspen detection using remote sensing are the low proportion and scattered occurrence of European aspen in boreal forests and the overlap of spectral and/or structural properties of European aspen and quaking aspen with some other tree species. Furthermore, the suitability of remote sensing data for aspen mapping and monitoring depends on the geographical coverage of data, the availability of multitemporal data and the costs of data acquisition. Our review highlights that

47 integration of ecological knowledge with spatiotemporal information acquired by remote sensing is key to understanding the current and future distribution patterns of aspen-related biodiversity. 


\section{Introduction}

Biodiversity loss is a global threat that deteriorates ecosystem function and thereby impacts the well-being of humans (Hooper et al., 2012; IPBES, 2019). Forest biodiversity has been negatively affected by modern large-scale forestry that has caused loss and fragmentation of pristine habitats and reduced structural heterogeneity in managed forest stands. Boreal forests cover large areas in northern Europe, but they are mostly intensively managed throughout their range. Moreover, managed boreal forests tend to be monocultures of conifers (Esseen et al., 1997; Mönkkönen et al., 2018; Seedre et al., 2018; Rodríquez et al., 2019). For biodiversity conservation and ecosystem services, this phenomenon is a drawback because mixed-species forests can provide important benefits. For example, they host greater species richness, are more resistant to pests and pathogens and have a higher capacity for carbon sequestration (Gamfeldt et al., 2013; Brockerhoff et al., 2017; Ampoorter et al. 2019; Rodríguez et al. 2019). Both living and dead deciduous trees play an important role in diversifying the structure and species composition of boreal forests (Kouki et al. 2004).

European aspen (Populus tremula L., hereafter 'aspen' or 'European aspen') is a keystone species and an early-succession species in boreal forests. Although it has a sparse and scattered occurrence in northern Europe, it contributes significantly to the biological diversity of boreal forest landscapes (Hynynen and Viherä-Aarnio, 1999; Kouki et al., 2004; Tikkanen et al., 2006; Whitham et al., 2006; MacKenzie, 2010; Caudullo and de Rigo, 2016). Aspen is an important host for many species. Aspen trees are inhabited by epiphytic bryophytes and lichens (Kuusinen, 1994; Gustafsson and Eriksson, 1995; Hazell, 1998; Pykälä et al., 2006), pathogens (Callan, 1998), herbivorous invertebrates (Robinson et al., 2012), mammals such as the flying squirrel (Pteromys volans; Hanski, 1998; Remm et al. 2017) and birds such as woodpeckers and owls (Hågvar et al., 1990; Angelstam and Mikusinski, 1994; Tikkanen et al., 2006; Hardenbol et al. 2019). Secondary hole-nesters, including many tits, flycatchers, owls, ducks and flying squirrels, are dependent on cavities excavated by woodpeckers (Martin and Eadie, 1999; Baroni et al. 2020). Aspen leaf litter is utilised by, for example, gastropods (Suominen et al., 2003), and dead and decaying aspen trunks provide a suitable habitat for myriad 
polypore fungi (Kotiranta and Niemelä, 1981; Hynynen and Viherä-Aarnio, 1999; Junninen et al., 2007) and saproxylic invertebrate species (Siitonen and Martikainen, 1994; Martikainen, 2001; Dahlberg and Stokland, 2004; Halme et al., 2012). The conservation biological importance of aspen is illustrated by the fact that many of the aspen-associated species-dependent either on living of dead aspen trees—are red-listed (Jonsell et al., 1998; Hynynen and Viherä-Aarnio, 1999; Dahlberg and Stokland, 2004; Tikkanen et al., 2006).

Given this keystone role, a continuous spatial and temporal supply of aspen trees is a prerequisite for maintaining viable populations of associated species in boreal forests (Kouki et al., 2004; Vehmas et al., 2009). Thus, information on the occurrence, abundance and regeneration of aspen is crucial for efficient planning and implementation of sustainable forest management measures and conservation efforts. Knowledge on changes in aspen occurrence and distribution is also important, because aspens can serve as an indicator of ecological integrity and landscape health (Kay, 1997). The widespread but patchy and clustered occurrence of aspen in boreal forests poses challenges for ordinary inventory and mapping methods (Maltamo et al., 2015). For example, the number of sample plots in traditional forest inventories is often too low to capture patchily occurring phenomena and their variation (Kangas, 2006). Recent advances in remote sensing technology hold much promise for obtaining systematic and rapidly updated information on the spatiotemporal distribution and characteristics of tree species over wide areas (Fassnacht et al., 2016). Thus, they can provide new opportunities to map key ecological features, such as aspen, in order to create spatiotemporally comprehensive biodiversity assessments (Pettorelli et al., 2014; Wang \& Gamon 2019).

A few earlier reviews examined European aspen or Populus tremuloides Michx. (quaking aspen, trembling aspen or American aspen) that occur in North America. A review by Landhäusser et al. (2019) focused on ecology, management and restoration of quaking aspen, and the review by MacKenzie (2010) examined ecology, conservation and management of both European aspen and quaking aspen in the northern hemisphere. Worrell (1995a, 1995b) reviewed the distribution, ecology and genetic variation - as well as values, silviculture and utilisation — of European aspen, with 
particular reference to Scotland. Myking et al. (2011) reviewed life history strategies of European aspen and the browsing effects on it. Furthermore, Rogers et al. (2020) reviewed conservation of aspen in a global context. The key aims of this review are to (1) collate existing knowledge on the ecological role of European aspen in boreal forests, (2) examine knowledge needs for aspen occurrence and dynamics and (3) study the potential of different remote sensing techniques in mapping aspen trees and stands at various spatiotemporal scales. We will identify current research gaps and new methodological opportunities that can increase our understanding of aspen-related biodiversity in rapidly changing forest landscapes (Hyvärinen et al., 2019). In the remote sensing section (section 4), we examine the mapping of European aspen, quaking aspen and a few other Populus species to cover the current knowledge on the topic as widely as possible.

\section{Aspen as a keystone species in boreal forests}

Aspen is a pioneer species in boreal forests and thus needs open areas or spots to regenerate and establish. It typically grows either in sites where there are no shading trees or as hold-overs in more closed forests, and it readily colonises new open areas. Aspen has a wide ecological amplitude, and it occurs in many forest types, from dry rocky areas to water-logged sites. Aspen reproduces both by seeds and root sprouts, with the latter being the most common and most successful form of reproduction.

Long-term aspen persistence in primeval old-growth forests has only recently received attention (Fig. 1a). Studies suggest that that aspens can live up to 100-200 years (Lilja et al., 2006; LatvaKarjanmaa et al., 2007; Vehmas et al., 2009), and aspen presence even in old-growth forests reaching the age of 450 years has been reported (Tarasova et al. 2017). According to Bergeron et al. (2014), gap dynamics play an important role in long-term persistence of aspen ( $P$. tremuloides) in low intensity disturbance regimes (i.e., areas where stand replacing disturbances are scarce) in North America. Single blowdowns of large dominant trees or small-scale windthrow areas allow selfreplacement of aspen through suckering (Groot et al. 2009, Reinikainen et al. 2012). However, in 
European Russia, birch and rowan appeared to be more common in gaps than European aspen 131 (Gromtsev et al. 2002).

Aspen leaf litter has a high calcium content, which can increase the $\mathrm{pH}$ of the typically acidic boreal forest soils. This fact has important consequences on the soil chemistry, ecosystem functioning and habitat availability for accompanying species (Koivula et al., 1999; Suominen et al., 2003; Nikula et al., 2010). Buck and St. Clair (2012) showed that the surface soil horizons of quaking aspen stands have higher mineral nutrient availability compared to other soil types. They proposed that aspen soils are biologically more active compared to other soil types. The $\mathrm{pH}$ of aspen bark varies widely among stands as well as within stands; measured stand averages range from 4.7 to 6.3 (Kuusinen, 1994). The relatively high bark $\mathrm{pH}$ can affect the abundance of epiphytic bryophyte and lichens that grow on aspens (Kuusinen, 1994; Gustafsson and Eriksson, 1995). In addition to chemical properties, aspen trees can provide unique physiological environments for associated species. For example, treedwelling bats favour aspen as their maternity roosts because they are both warmer and safer than other tree species (Michaelsen, 2016).

The occurrence, abundance and diversity of the aspen-associated species are markedly affected by the characteristics of individual aspen trees, including size and age. Many species prefer or are confined to old aspens, and large-diameter host trees are favoured, for example, by epiphytic bryophytes (Hazell et al., 1998; Gu et al., 2001). Due to this factor, large aspens with a diameter at breast height that exceeds $20 \mathrm{~cm}$ (Latva-Karjanmaa et al., 2007) or $25 \mathrm{~cm}$ (Maltamo et al., 2015) have been included as ecologically relevant individuals in studies that aimed to map the spatiotemporal variation in aspen abundance. Black-coloured and speckled bark, slow tree growth (as defined by visual inspection, e.g., the relationship between the diameter and bark texture) and tree inclination angle are also important determinants of epiphytic lichen species on aspen trees (Perhans et al., 2014).

153 Further, the number of epiphytic bryophyte species increases with aspen bark thickness (Gustafsson 154 and Eriksson, 1995). Tarasova et al. (2017) also found distinct epiphyte species composition at 
different heights of aspen trunks and branches. These data show that disparate lichen and moss species often occupy different ecological niches (Fig. 1b).

In addition to the characteristics of individual aspens, local- and landscape-level factors can impact species assemblages associated with aspen trees. For example, field-layer vegetation of the forest (Gustafsson and Eriksson, 1995; Hazell et al., 1998) and forest stand structure, i.e., accompanying tree species (Hazell et al., 1998), affect the abundance of bryophytes on aspens. Furthermore, the amount of light in a forest stand affects the number and community composition of epiphyte species (Gustafsson and Eriksson, 1995). An increased density of spruce causes more shading that, in turn, increases the abundance of certain bryophyte species (Hazell et al., 1998). Long-term persistence of aspen in the landscape is critical for the continuance of aspen-related species. Aspen-associated species, such as epiphytic lichens, may persist in the remaining small patches of host trees for some time ( $\mathrm{Gu}$ et al., 2001), but ultimately their populations become increasingly threatened as the resources they need decrease in the landscape. Suominen et al. (2003) showed that the connectivity of habitats and large aspen stand sizes, at least $500 \mathrm{~m}^{2}$, are important determinants for abundance and diversity of gastropods that live on aspen leaf litter. In general, information on aspen occurrence and dynamics at the landscape level in the boreal zone is scarce. Latva-Karjanmaa et al. (2007) estimated that $50 \%$ of the mature aspens of an old-growth forest in the studied nature protection area in eastern Finland will die within the next 30 years, and only $10 \%$ of existing trees will survive over 90 years.

The number of species that live on dead aspen wood material is high. Thus, the occurrence of this material is of critical importance for species richness and biodiversity conservation (Martikainen et al., 2000; Kouki et al., 2004). Aspen decay is a rather fast process; most of the current dead wood will become disintegrated within about 90 years, depending on the current decay stage (LatvaKarjanmaa et al., 2007). The continued supply of dead wood depends on the regional abundance of aspen trees and the disturbances that generate fallen and dead trunks. For example, several threatened aspen-specialist polypore species require frequent emergence of new suitable host trees as old ones become unsuitable for them in approximately 10 years after colonisation (Martikainen et al., 2000). 
Similarly, saproxylic insect species that utilise recently dead aspen wood are dependent on

sufficiently rapid formation of new habitats (Ranius et al., 2011). Saproxylic invertebrates that live on decaying wood can often colonise several tree species and therefore are not always dependent on the occurrence of one species. However, species composition of the saprophytic fungi community may crucially impact the habitat quality for many saproxylic insects (Jonsell et al., 1998). Likewise, nematorecan (Diptera) communities of a single aspen log may markedly differ between the base and top part of the same tree, but the factors that determine this variation and the preferred microhabitat for each insect species are poorly understood (Halme et al., 2013). Økland et al. (1996), Ranius et al. (2011) and Jacobsen et al. (2015) demonstrated that species richness of aspen-associated saproxylic beetles can be related to dead wood volume within a radius of $0.1-3 \mathrm{~km}$. These findings highlight the importance of habitat availability at larger scales.

Aspen has a clonal growth habit, in which several ramets can emerge from one clone as root sprouts. However, clones of European aspen often consist of a single ramet. For example, in a Finnish study, $70 \%$ of the clones comprised only one ramet (Suvanto and Latva-Karjanmaa, 2005). Genetic studies revealed that intrapopulation genetic variation of European aspen is relatively high. These data imply that the proportion of individuals that arise from seeds is higher than previously assumed (Suvanto and Latva-Karjanmaa, 2005). On the contrary, quaking aspen can form giant growth, with the largest known genet covering about 43.6 ha (DeWoody et al., 2008). Nevertheless, quaking aspen also exhibits much more genetic variation than previously presumed, with many clones encountered only once in a $50 \mathrm{~m}$ grid (Mock et al., 2008). In European aspen, the maximum distance between ramets in a clone can be at least $46 \mathrm{~m}$ (Suvanto and Latva-Karjanmaa, 2005). In Scotland, 21 clones were detected in a 4.6 ha area, when 186 aspens were sampled (Easton, 1997). 


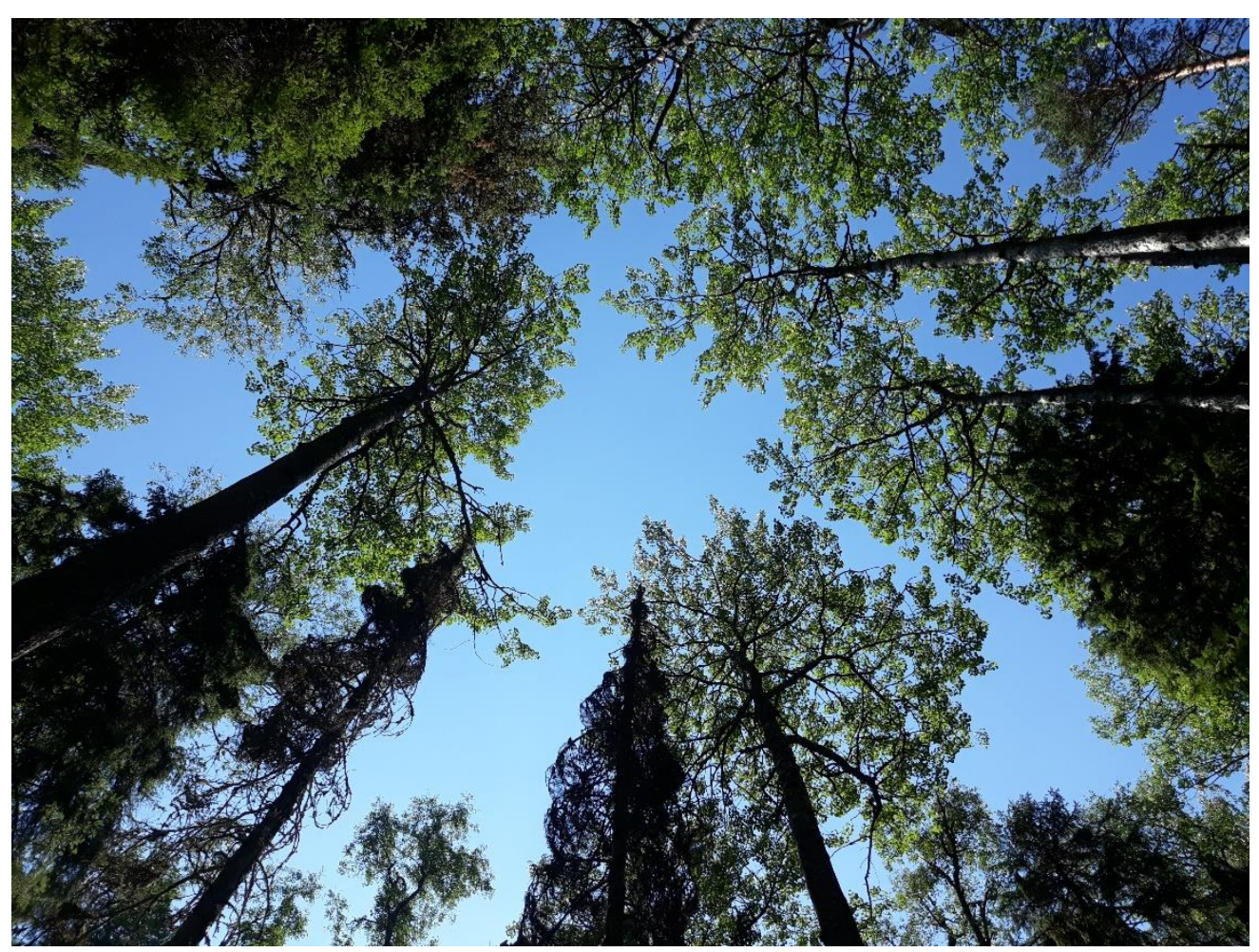

209

210 b)

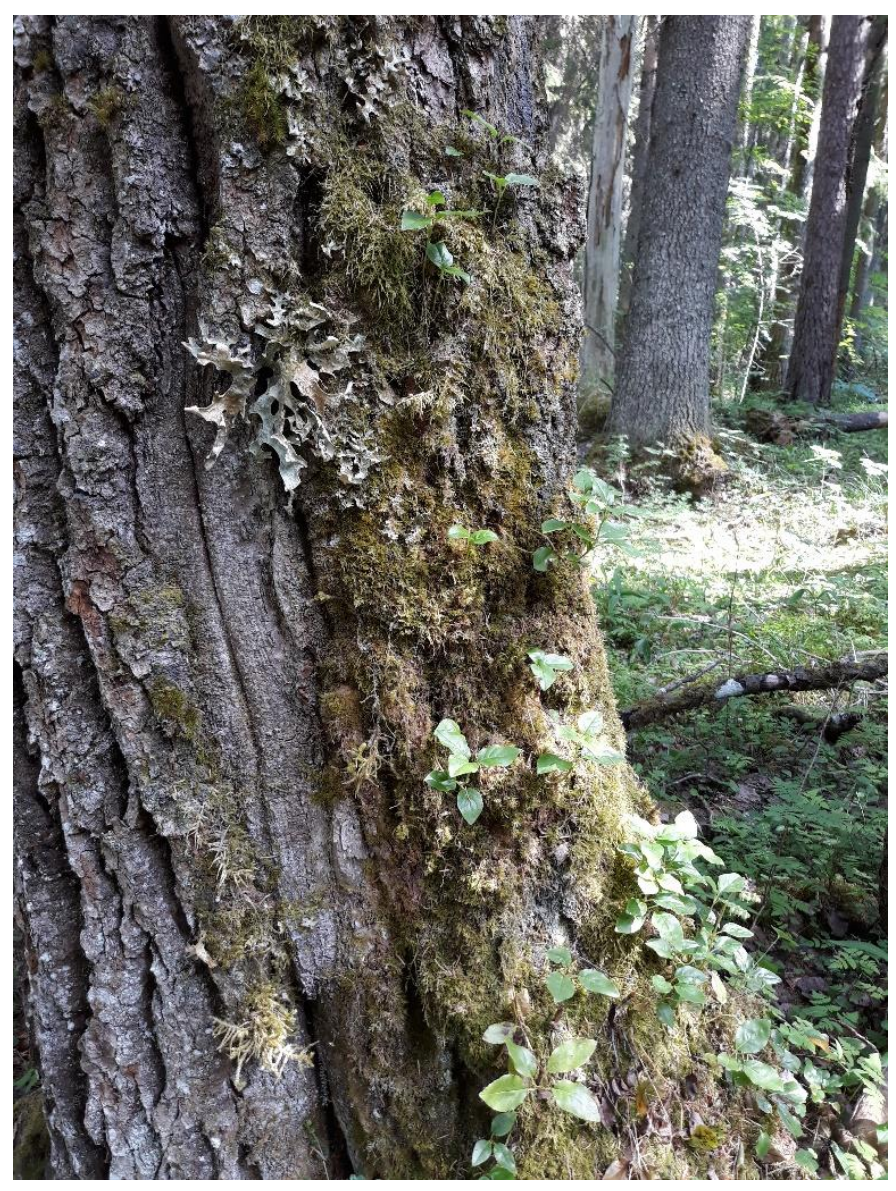


Fig. 1.a) Crowns of aspen hold-overs in a natural old-growth forest that reach above below-growing

213 spruce trees. b) Aspen trunk with epiphytic lichens, mosses and Orthilia secunda. (Photo credits:

214 Sarita Keski-Saari.)

\section{Major drivers of aspen occurrence and dynamics in boreal forests}

\subsection{Forest management methods}

Forest industry and management in Fennoscandia has traditionally favoured conifers (Picea abies,

Pinus sylvestris) over aspen. Thus, over the years aspen trees have been eradicated both mechanically and via herbicides, particularly during 1950-1980 (Östlund et al., 1997; Rouvinen et al., 2005; Latva-

Karjanmaa et al., 2007). Such forestry actions were justified by the presumed harmful effects of aspens to the more valued conifers. Aspen acts as a host for decaying fungi and rust diseases, such as Melampsora pinitorqua, that occur in young pine stands (Östlund et al., 1997), and competition with fast-growing aspen can obstruct the growth of conifers (Yang, 1991; Filipescu and Comeau, 2007). Aspen regeneration and establishment are dependent on disturbances, including storms and fires. In contrast, lack of natural disturbances favours coniferous species over deciduous ones. The prevailing forest management practices during the last two centuries have clearly favoured conifers over deciduous species; indeed, efficient fire suppression has almost eliminated fires as a rejuvenating factor from the boreal forests of Sweden and Finland (Zackrisson, 1977; Kouki et al., 2004; de Chantal et al., 2005; Lankia et al., 2012). Edenius et al. (2011) reported that aspen regeneration has declined since the 1970s in Sweden due to the large-scale transformation of land use together with mechanical clearing of deciduous trees and the use of herbicides (Fig. 2a).

Recently, aspen has received more supportive consideration-based on the realisation of its keystone species role in forest biodiversity_in the management planning of commercial forests. The most important recommendations to secure aspen regeneration include restoring regeneration niches by mimicking natural disturbance processes, such as fire at various spatial scales, and retaining aspen 
in clearings and pre-commercial thinnings (Kouki et al., 2004; Vanha-Majamaa et al. 2007; Edenius et al., 2011). Clear-cutting acts as a source of disturbance and promotes the regeneration of aspen.

240 How this is realized in the number of mature aspens depends on forestry actions following the 241 regeneration, such as thinning of seedling stands (Fraser et al. 2003). Similarly, the extent of tree retention is dependent on the forestry actions (Latva-Karjanmaa et al., 2007; Myking et al., 2011; Kuuluvainen et al. 2019). Creating dead wood by girdling aspens or leaving dead wood on clear-cuts may represent beneficial measures to preserve species that are dependent on dead aspens (Jonsell et al., 1998; Martikainen et al., 2000; Runnell et al. 2012), but could be harmful for species dependent on old living aspens.

247 The use of retention trees has been considered an important measure to halt forestry-related loss of aspen-associated species (Martikainen, 2001; Hedenås and Hedström, 2007; Junninen et al., 2007; Sahlin and Ranius, 2009; Lundström et al., 2013). In northern Europe, aspen has been widely favoured as a retention tree; there are many studies that show the efficacy of retained aspens on biodiversity (Rosenvald and Löhmus, 2008; Gustafsson et al., 2010; Lundström et al., 2013; Fedrowitz et al., 2014; Perhans et al., 2014) (Fig. 2b). However, it is important to acknowledge that there are also species that perform poorly on retention aspens (Hedenås and Hedström, 2007). Furthermore, there is a need to improve the efficiency of retained aspens for biodiversity by adding their numbers and using ecologically meaningful tree characteristics (e.g., black-coloured bark, slow tree growth, inclined stems and speckled bark) for their selection as retention trees (Perhans et al., 2014).

The retention trees are prone to wind disturbance (Jönsson et al., 2007). The post-harvest mortality rate is high with retained aspens as well, $46 \%$ of them reported fallen after six years of monitoring (Rosenvald et al. 2008) and $52 \%$ after 16 years of monitoring (Rosenvald et al. 2019). Hence, not 261 only it is essential to select high ecological value aspens, but they should also have qualities of high survival (e.g. large tree diameter, position near forest edges, high retention density) (Rosenvald et al., 
2008; Hämäläinen et al., 2016). Nevertheless, the fallen retained aspens may also be valuable habitats

264 (Junninen et al., 2007; Rosenvald et al. 2019).

In Finland, leaving aspens standing as retention trees has had positive effect on some species previously categorised as Near Threatened and even on certain species previously classified as Threatened. This improvement has aided their red-listing status to be re-classified as Least Concerned species (Rassi et al., 2010). Large aspens are generally the most important for biodiversity, and hence they are generally favoured as retention trees (e.g., Kolström and Lumatjärvi, 2000). However, Schei et al. (2013) found that, at least for lichen species, retention of young aspens may also be a beneficial practice as they have a longer expected persistence compared to old aspens. Lundström et al. (2013) showed that the number of aspen-dependent lichen species on retention aspens can be lower in recently harvested stands compared to stands harvested 10-16 years ago. This finding may imply that species that favour more interior forest conditions persisted, and in addition, new species that are adapted to open environments colonised the retention trees.

The response of different species to retention trees appears to be species-dependent. For example, cyanolichens often inhabit retention trees, whereas green algal lichens show contrasting habitat preferences: they are more abundant in closed forests compared to retention trees (Hedenås and Hedström, 2007). Approximately $80 \%$ of the threatened saproxylic invertebrates in Sweden occur in open environments. Thus, they are likely to benefit from retention trees, while the species that require shadow or semishade will not (Jonsell et al., 1998). Oldén et al. (2014) concluded that in order to be as effective as possible, retention trees should be left adjacent to conservation sites, which can function as sources of re-colonisation and support the populations of species that require old-growth forests. Similarly, Hedenås and Ericsson (2000) and Hedenås et al. (2007) highlighted that a prerequisite for new-establishment in spore dispersed lichen species is that there are old aspen stands that act as source populations in the surrounding landscape. Moreover, the quantity of retention trees should be substantial to prominently support, for example, the survival of accompanying forest vegetation (Johnson et al., 2014). Sverdrup-Thygeson et al. (2014) highlighted that retention patches, 
289 woodland key habitats and nature reserves all have important and complementary functions for wood290 living species in boreal forests.

291

292 a)

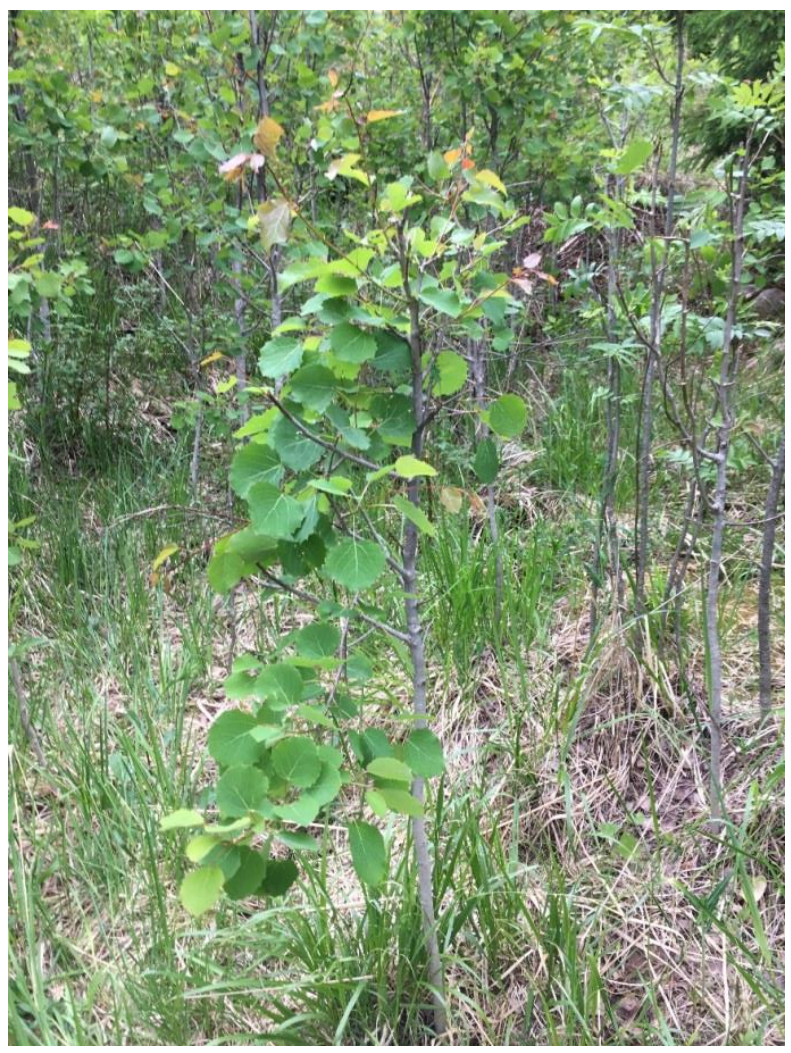


b)

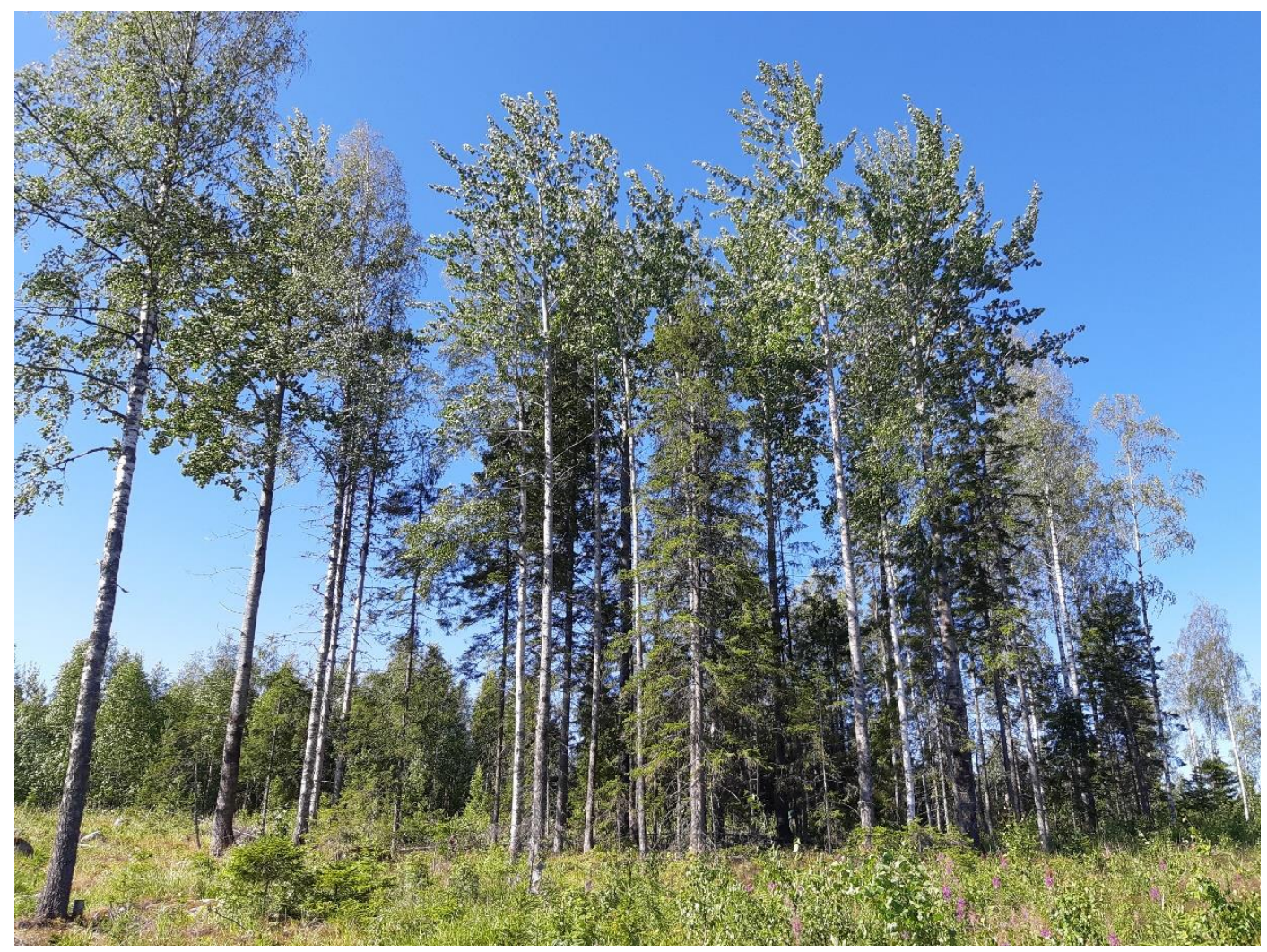

Fig. 2.a) A young aspen in a clear-cut (Photo credit: Sonja Kivinen). b) A group of retention trees including aspen. (Photo credit: Sarita Keski-Saari)

\subsection{Herbivores and pathogens}

311 European aspen shoots and leaves provide valuable nutrition to several herbivore species, as reviewed by Myking et al. (2011). Browsers can suppress the regeneration of aspen and, in the longterm, reduce recruitment, delay maturation, increase mortality and ultimately cause a decline in local 314 aspen populations. High browsing pressure is thus a major threat to species that are dependent on old 315 aspens (Kouki et al., 2004; Komonen et al. 2020). Moose (Alces alces) is the primary herbivore that 316 affects aspen recruitment (Edenius and Ericsson, 2007; Edenius et al., 2011). Fennoscandian moose 317 populations started to grow rapidly in the 1960s, due to suitable habitats produced by clear-cutting, 318 the low numbers of large carnivores and the use of supplementary forages, and are currently among 319 the most productive and heavily harvested moose populations in the world (Lavsund et al., 2001). A 
recent increase in the number of roe deer (Capreolus capreolus) and red deer (Cervus elaphus) also causes high browsing pressure on aspens (Myking et al., 2011). Similarly, intense browsing by ungulates is harmful to the establishment and recruitment of quaking aspen in North America (Seager et al., 2013; Rhodes et al. 2017).

Edenius et al. (2007) found that heavy browsing in the absence of either human-caused or natural disturbances accelerates succession towards conifer dominance. However, Myking et al. (2011) emphasised that more research is needed on how browsing interacts with other factors and affects the spatiotemporal variation in recruitment rates and population dynamics of aspen. Additional data are also needed on ungulate densities that allow the maintenance of viable aspen populations in different habitats (Edenius and Ericsson, 2015). An important management tool could be protecting established aspen ramets at designated sites from browsing either by fencing or reducing ungulate numbers (Kouki et al., 2004; Edenius et al., 2011). After forest fire, aggregations of dead wood can act as browsing refugia for aspen seedlings (de Chantal and Granström 2007), and one option would be to leave $\operatorname{logs}$ in a crisscross arrangement to provide dead wood and a barrier against herbivores (LatvaKarjanmaa et al., 2007).

In addition to moose, hares (Lepus sp.) and voles (Microtus and Myodes sp.) have a high preference for aspen (Hjältén et al., 2004). For example, in an old-growth forest in northern Finland, hare browsing was as frequent for saplings as moose browsing (Latva-Karjanmaa et al., 2007). Insect herbivory apparently has a limited impact on both aspen survival and growth. For example, arthropod herbivore abundance and species richness co-occurred with the highest tree growth in a common garden experiment in Sweden. This finding indicates that the trees preferred by insects maintained the highest growth in the subsequent year (Robinson et al., 2012). On the other hand, pathogens may seriously hamper aspen regeneration. The number of pathogen species that occur on aspens is notably high (Callan 1998). For example, Venturia tremulae fungus has a high capacity to cause epidemics; by attacking aspen seedlings, it can decrease growth and even cause aspen tree death (Kasanen et al., 2004). 


\subsection{Climate warming}

Climate warming results in elevated mean temperatures and changes in precipitation in northern areas (IPCC, 2018). Aspen is a thermophilic species that is expected to benefit from rising temperatures in boreal forests. Accordingly, elevated temperature facilitates aspen growth (Sivadasan

et al., 2018). On the other hand, drought can seriously hamper the growth of aspen trees, and sexual reproduction and seedling establishment of aspen are strongly dependent on adequate moisture (Latva-Karjanmaa et al., 2003; Singer et al., 2019). Moisture stress also negatively impacts the growth of aspen seedlings (Nikula et al., 2011; Possen et al., 2011). As a general rule, increased occurrence of disturbances, including storms and forest fires (IPCC 2018), may benefit aspen regeneration. However, severe fires can actually be harmful because they may hamper the formation of root suckers if roots are damaged by the fire. Different IPCC climate scenarios are likely to promote distinct species combinations, depending on the projected outcome of the host tree species. For example, saproxylic species associated with aspen may benefit from future climate characterised by an intermediate rise in temperatures, whereas an extreme rise would negatively affect them (Mazziotta et al., 2012).

Van Bogaert et al. (2010) estimated that aspen has become approximately 16 times more abundant in subarctic Sweden over the past 100 years, mainly due to increased sexual regeneration. According to their study, aspen colonisation at the tree line is mainly restricted by summer temperature, whereas disturbances caused by moth population outbreaks in birch forests are critical for aspen establishment at lower elevations. Future aspen occurrence and abundance in these areas will thus be driven by complex relationships among changing disturbance regimes, future herbivore population dynamics and responses of birch and pine to changing climate. Van Bogaert et al. (2009) found that moth outbreaks on birch stimulate the recruitment of aspen, but aspen stand expansion can be strongly 
371 is thus likely to be dependent on the number of vertebrate browsers relative to the number of aspen 372 recruits.

\subsection{Spatial and temporal knowledge needs}

375 Many of the ecological studies that we reviewed highlight the significant ecological role of aspen 376 in boreal forest ecosystems in northern Europe. These studies also call for acquisition of accurate 377 spatiotemporal information on aspen occurrence and abundance, which is currently scarce and 378 incomprehensive (Fig. 3). Spatial distribution, size and age of aspen trees are highly relevant 379 information. These data will enable assessing the landscape's ability to support viable populations of 380 aspen-associated species. This information will also be of significant importance in understanding 381 the contributions of retention trees on aspen-related biodiversity.

382 A crucial ecological question is the long-term persistence of aspen in boreal forest landscapes. 383 Aspen dynamics and regeneration are driven by various anthropogenic, biotic and abiotic factors, as 384 well as the relationships among these elements. Time series analysis of aspen dynamics will increase 385 the understanding of the role of different factors on aspen persistence and enable estimates of current 386 and future status of aspen-related species. Information on the abundance of aspen trees in a landscape 387 will also provide estimates for the continuum of dead aspen wood, which is of critical importance for 388 many species. Furthermore, the ability to produce spatial and temporal information on aspen at 389 different spatial scales would facilitate more efficient planning and implementation of forest management measures and conservation efforts. 


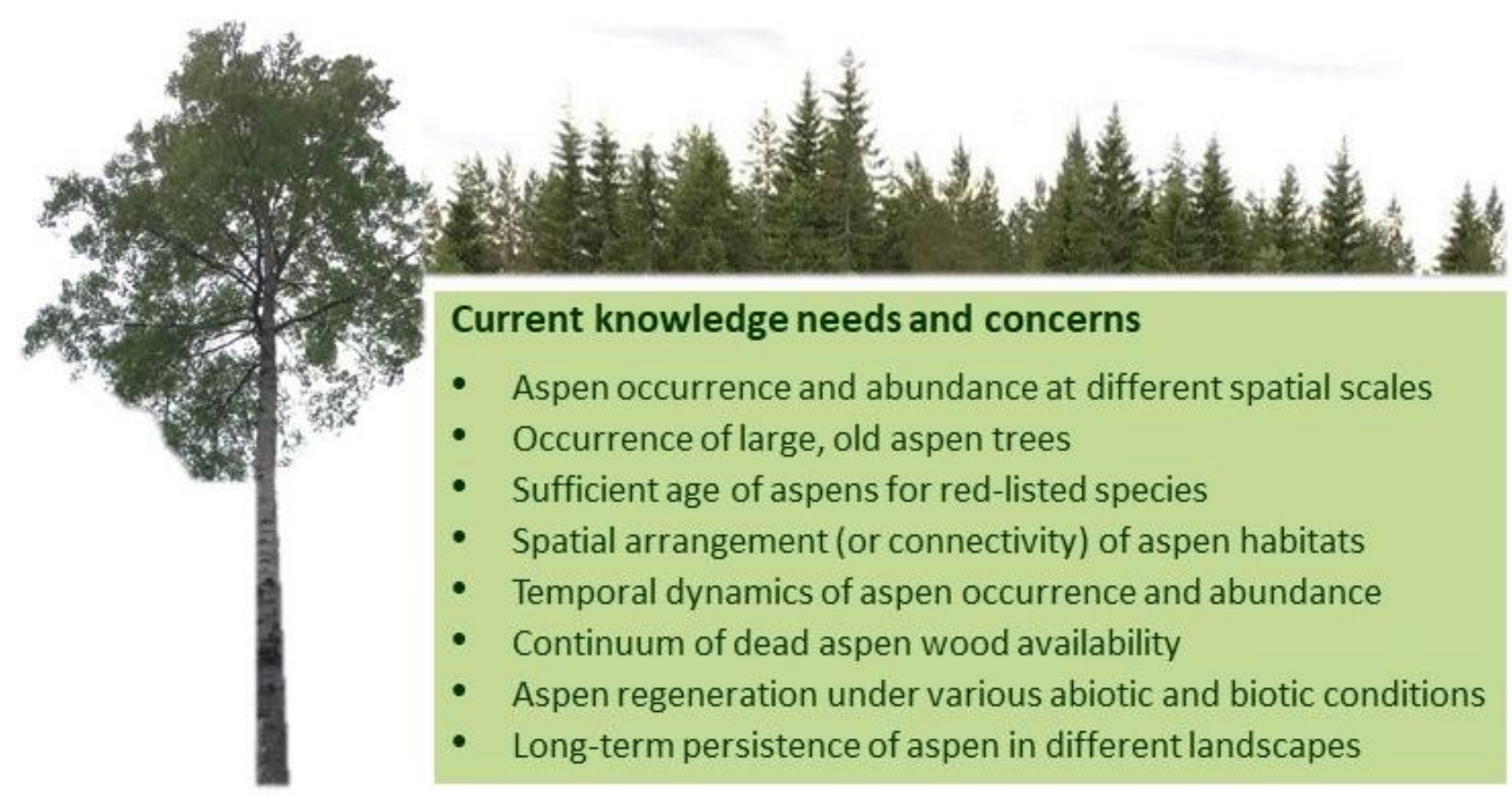

393 Fig. 3. Current knowledge needs and concerns related to European aspen in boreal forest

394 landscapes.

4. Mapping aspen occurrence and dynamics using remote sensing

\subsection{Remote sensing techniques in vegetation mapping}

Various remote sensing techniques enable timely and spatially explicit mapping of land cover.

They can provide significant opportunities in acquiring information on the occurrence and dynamics

of keystone species, such as aspen, in changing forest environments at various spatial and temporal

401 scales (Ghosh et al., 2014). Remote sensing data can be acquired with unmanned aerial systems (UAS, also referred as drones), planes and satellite platforms. Depending on the platform and sensor, the spatial resolution (pixel size) of the imagery can range from some centimetres to hundreds of metres.

Similarly, the geographical extent of the data can vary from local to global coverage.

Spectral remote sensing data consists of spatial images where every pixel contains the intensity of electromagnetic radiation reflected or emitted from the target and recorded by a sensor. Optical remote sensing is based on detecting objects at different wavelengths from visible and near-infrared 
infrared range (LWIR; 8000-14000 nm). Spectral resolution, i.e., the number and width of spectral bands in which information is recorded, varies between the sensors. Multispectral imagery consists of several generally non-contiguous spectral bands of varying bandwidths, whereas hyperspectral images (imaging spectroscopy) include a contiguous spectral range with hundreds of narrow bands. Temporal resolution refers to how often the remote sensing system records imagery of a particular area (revisit time; see Xie et al., 2008).

Aerial photography (panchromatic [black and white], colour [red, green, blue or RGB], or colourinfrared [CIR, also referred as false-colour]) is a traditional remote sensing technique to acquire information on vegetation cover. Today, digital aerial imagery acquired from aircraft provides detailed information on tree species, and these data have been widely utilised in national forest inventories both for direct measurements and as auxiliary information (Haara and Haarala, 2002; Persson et al., 2004; McRoberts and Tomppo, 2007). Time series of aerial imagery enable tree-level and stand-level detection of vegetation changes.

Rapid UAS development has mediated the development of new forestry-oriented applications (Colomina and Molina et al., 2014; Torresan et al., 2016; Franklin, 2018). The possibility of acquiring very high spatial resolution multispectral or hyperspectral UAS imagery on-demand allows estimating the structural parameters of forests at individual tree and stand level with high accuracy (Zarco-Tejada et al., 2014; Puliti et al., 2015). Recent developments in image processing software have also enabled wide-scale production of photogrammetric point clouds (PPC). PPCs have an RGB or near-infrared (NIR) value for each point, a feature that provides both colour information and the three-dimensional structure of the canopy (Hirschmuller, 2008; St-Onge et al., 2008). Airborne hyperspectral imagery (aircraft or UAS) provides new possibilities for increased accuracy of tree species mapping (Naidoo et al., 2012; Dalponte et al., 2013; Feret and Asner, 2013; Trier et al., 2018). High spatial and spectral resolution enables mapping biochemical and biophysical properties of vegetation (Alchanatis and Cohen, 2012; Roberts et al., 2012) that can be further used in species classification (Ghosh et al., 2014; Piiroinen et al., 2017). 
Multispectral satellite imagery allows vegetation mapping from local to global scales. Satellite images generally have coarser spatial resolution compared to airborne data, and thus these data can 437 be utilised in mapping tree groups or stands rather than individual trees. Multispectral data can be utilised to calculate spectral indices, such as normalised difference vegetation index (NDVI), to study the vegetation cover (Tucker et al., 1979). Temporal resolution of satellite imagery is typically 4-16 days, and the availability of long-time series (e.g. Landsat program) enables decadal change detection 441 (Wulder et al., 2008, 2019; Xie et al., 2008).

Airborne laser scanning (ALS), also commonly known by Light Detection And Ranging (LiDAR), is a remote sensing method that provides three-dimensional information on vegetation structure 444 (Beland et al., 2019). Unlike the above mentioned (passive) remote sensing techniques, ALS is an active method that is not dependent on prevailing lighting conditions. The ALS system is based on measuring the time between emitting a laser pulse and receiving its backscattered echo. Once the exact position and angle of the scanner are known, the time measurements can be transformed into three-dimensional point clouds that depict the shape and structure of the scanned objects. The accuracy of ALS metrics depends upon pulse density, i.e., the number of laser pulses that intercept the surface per unit (spatial resolution). Currently, the pulse density of ALS data can be tens of measurements per square metre, whereas the spectral resolution is typically restricted to a single wavelength. Multispectral ALS data are available but they are rare compared to single-wavelength data. Species classification using single-wavelength ALS data is based on differences in crown shape, density and reflectivity (Naesset, 2007, 2009; Maltamo and Packalen, 2014; Maltamo et al., 2018), whereas multispectral data enables using both spectral and structural characteristics (Budei et al., 2018).

Fig. 4 summarises the general advantages and drawbacks of different airborne and spaceborne remote sensing techniques in tree-species mapping. In the following case studies, we examine aspen detection at the tree-level and stand-level. The remote sensing studies reviewed here include mapping of European aspen, quaking aspen and a few other Populus species in Europe and North America. 


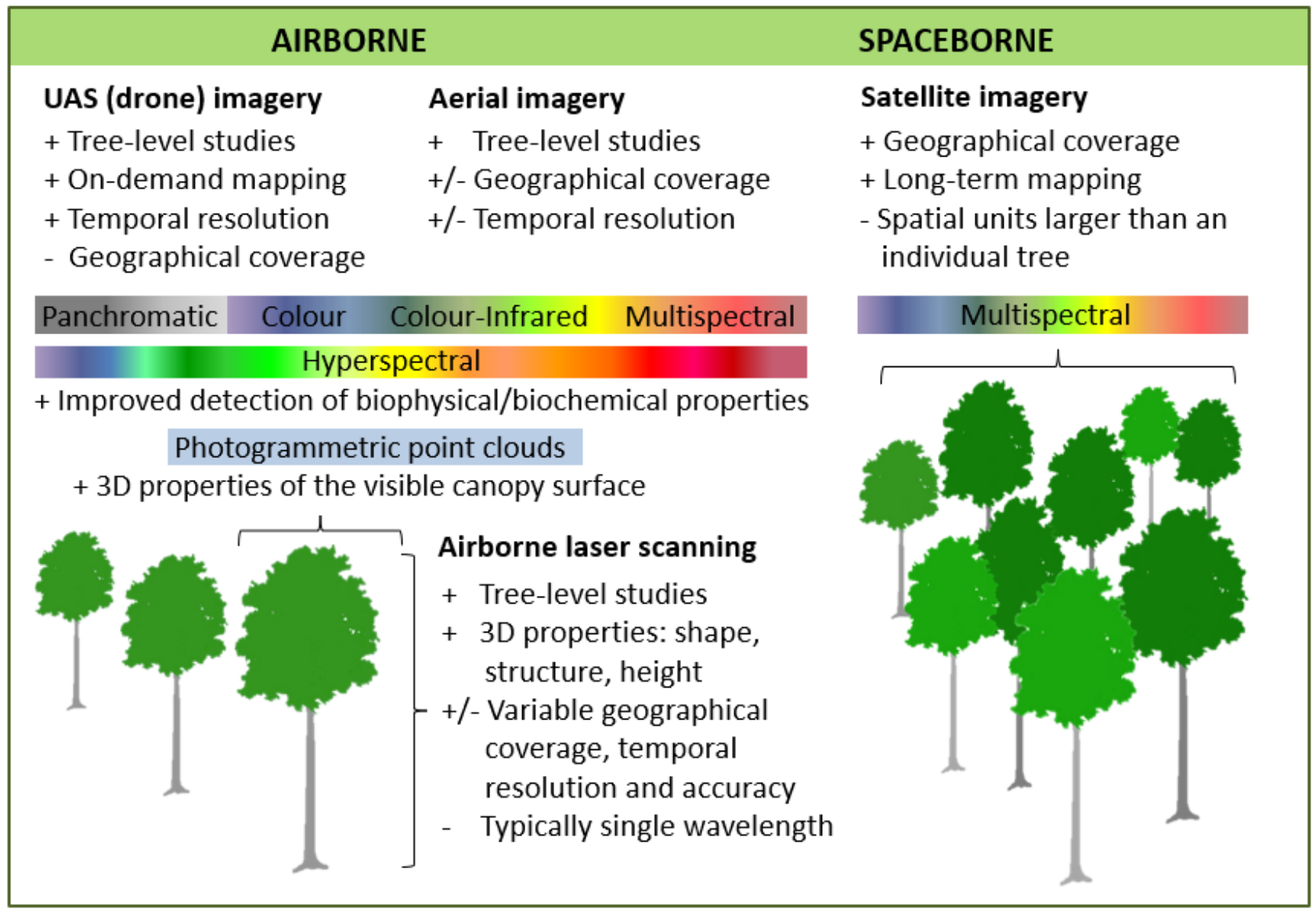

462 Fig. 4. Advances and drawbacks of different remote sensing techniques in tree-species mapping.

\subsection{Tree-level studies}

Aspen has been mapped at the tree-level using ALS, airborne photogrammetry and multispectral and hyperspectral imaging or the combination of different datasets. Table 1 provides detailed information on the case studies examined here. In many of these studies, the accuracy of tree species classifications is often evaluated based on the user's and producer's accuracy. User's accuracy (UA) reflects the reliability of classification for the class under consideration. It is calculated by dividing the number of correctly classified objects (e.g., segments or pixels) in a class by the total number of objects assigned to that class. The producer's accuracy (PA) relates to the probability that a ground reference object is correctly classified (i.e., it measures how well the class has been identified). It is obtained by dividing the number of objects correctly classified in a given class by the number of reference objects in that class (Prisley and Smith, 1987). 
based tree-level and stand-level studies due to the low number of aspen trees in the datasets (Packalen and Maltamo, 2007; Holmgren et al., 2008; Korpela et al., 2010; Ørka et al., 2010). However, there are some studies where aspen was classified separately from other tree species. Ørka et al. (2007) studied tree species classification by utilising ALS intensity metrics in the Østmarka natural reserve, Norway, where generally large and old aspens have a scattered occurrence in the forest landscape. Classification accuracies for aspen were relatively low $(\mathrm{PA}=24 \%, \mathrm{UA}=56 \%)$ compared to other species (64-87\% for P. abies L. and Betula ssp.). Laser metrics of aspen overlapped with those of spruce. Similar results were also reported by Korpela et al. (2010). In Canada, Li et al. (2013) classified tree species based on structure and architecture of individual tree crowns derived from highdensity ALS data. Unlike in Fennoscandia, quaking aspen (P. tremuloides Michx.) was the dominant tree species together with sugar maple (Acer saccharum Marsh.), jack pine (Pinus banksiana Lamb.) and eastern white pine (Pinus strobus L.). UA and PA for quaking aspen were $74 \%$ and $76 \%$, respectively, the highest classification error being between aspen and jack pine. The results of Li et al. (2013) highlight a positive, strong relationship between ALS point density and species classification accuracy.

Combining ALS data with aerial images can improve discrimination of tree species. Säynäjoki et al. (2008) used ALS data and aerial images to discriminate aspen from other deciduous trees in the Koli National Park in Eastern Finland, where abundance of European aspen is generally higher compared to typical managed boreal forests. Deciduous trees were first separated from coniferous trees using aerial images. Segments that belonged to aspen and those that belonged to other deciduous trees were then classified using ALS data with 79\% accuracy. Large aspen trees with diameter at 497 breast height of $>25 \mathrm{~cm}$ were detected with greater success compared to smaller trees. Breidenbach 498 et al. (2010) utilised the semi-individual tree crown approach based on ALS and multispectral aerial images to predict species-specific forest inventory attributes for different tree species. The study was conducted in a forest area in southern Norway, where the European aspen proportion was 
approximately $2 \%$. Relative root mean square error (RMSE) for aspen volume was significantly higher $(222 \%)$ compared to the relative RMSE for volume of pine, spruce and birch (38, 40 and $101 \%$, respectively). These data indicated that the predictions calculated for aspen were considerably less accurate compared to other tree species.

Aspen has also been classified using only aerial imagery or UAS imagery. Erikson (2004) utilised high-spatial resolution colour infrared aerial images to automatically classify segmented tree crowns of the four most common tree species (Picea abies Karst., Pinus sylvestris L., Betula pubescens Ehrh. or Populus tremula L.) in boreal forest landscape in Sweden. In that study, the proportion of aspen of all trees was approximately $3 \%$, and the UA and PA were $63 \%$ and $71 \%$ respectively. Franklin and Ahmed (2017) studied deciduous forest species classification in a Canadian hardwood forest using multispectral UAS imagery. Crowns of quaking aspen were represented by bright and distinctive 512 tones on colour and near-infrared images, and no classification errors were reported. However, it 513 should be noted that validation of classification was based on relatively small sample of trees. Alonzo 514 et al. (2018) utilised UAS-based RGB point cloud to classify trees species in interior Alaska. The dominant species in the studied boreal forest area were black spruce (Picea mariana Mill.), white spruce (Picea glauca (Moench) Voss), birch (Betula papyrifera Marshall) and quaking aspen. The 517 UA and PA for quaking aspen were $83 \%$ and $74 \%$, respectively. The results showed that the inclusion 518 of spectral information is critical to supplement structural information in tree species classification. adequate information to discriminate among spectrally similar targets. Jones et al. (2010) used a combination of ALS and imaging spectroscopy for tree species classification in Canada. Several broad-leaved tree species, including quaking aspen and black cottonwood (Populus trichocarpa), occurred commonly in the studied forest area dominated by Douglas fir (Pseudotsuga menziesii).

524 Although the methodology enabled species mapping with more detail and accuracy than is possible using conventional approaches (i.e., interpretation of aerial images), or either technology on its own, classification accuracies were markedly lower for quaking aspen (UA and PA $<34 \%$ ) due to 
similarity with red alder (Alnus rubra). However, another Populus species, black cottonwood, was accurately classified (UA of $82 \%$ and PA of $98 \%$, respectively). Dalponte et al. (2009) used airborne imaging spectroscopy to image two Italian forest areas; one of them had a dense forest with 19 different tree species. Two Populus species, Populus canescens and Populus hybrida, were identified with UAs of approximately 80-90\%, depending on the applied differentiation classifier. Similarly, Roth et al. (2015b) utilised airborne imaging spectroscopy to differentiate a large number of tree species in different regions in the USA and studied the impact of spatial resolution of data on classification accuracy. For black cottonwood, UAs and PAs were $82-100 \%$ for up to $40 \mathrm{~m}$ resolution and $71-83 \%$ at $60 \mathrm{~m}$ resolution. These data highlight the fact that future spaceborne imaging spectroscopy has high potential in tree species mapping. In another study, Roth et al. (2015a) compared the accuracy of imaging spectroscopy in species detection across different ecosystems and classified $P$. trichocarpa with a UA of $87 \%$ and PA of $84 \%$. Tuominen et al. (2018) examined tree species recognition for 26 species and 14 genera in a Finnish arboretum using UAS-based hyperspectral imagery in combination with a three-dimensional photogrammetric canopy surface model. The UA and PA for aspen were $86 \%$ and 63\%, respectively. Saarinen et al. (2018) assessed plot-level biodiversity indicators using imaging spectroscopy and photogrammetric point clouds 543 acquired from a UAS in Finland. The number of aspens was low in the study region that contained 544 both managed and natural boreal forests. The largest errors occurred in predictions of the amount as well as the volume of deciduous trees, such as aspen.

\subsection{Stand-level studies}

The majority of scientific studies on aspen mapping at the stand level were performed in North America, where quaking aspen forms extensive pure stands. In particular, a recent phenomenon, referred to as sudden aspen decline, characterised by rapid overstory mortality with little to no understory regeneration (e.g., Singer et al., 2019), has resulted in numerous efforts to map aspen 
examples presented here can provide a general view on the possibilities and constraints of different

remote sensing methods in mapping aspen occurrence and dynamics at spatial scales coarser than individual tree-level (Table 1).

ALS- and UAS-based methods can provide estimates of tree density, basal area and aboveground biomass. In addition to individual tree detection, Alonzo et al. (2018) collected forest inventory variables at the plot-level using a UAS-based approach (see section 4.2). The accuracy of tree density, basal area and above-ground biomass estimates was somewhat variable. For example, quaking aspen basal area was accurately estimated, whereas the aboveground biomass of quaking aspen and other broadleaf species was frequently overestimated at the expense of white spruce ( $P$. glauca (Moench) Voss). In Finland, Pippuri et al. (2013) predicted species-specific basal areas in urban forest for seven dominant species, including European aspen, using ALS data and aerial images. Their results showed that separation of different deciduous tree species based on aerial images and ALS metrics is difficult. The accuracy of basal area estimates for European aspen was considerably lower compared to those for dominant coniferous species.

Aerial images can provide detailed information on forest stands at local and landscape scales. For example, Strand et al. (2012) mapped local dynamics of quaking aspen in Idaho over nearly four decades using aerial images. Stand structure was visible in the colour and infrared aerial images, but stands were difficult to delineate in older black and white images, a factor that complicated comparisons from one time period to another. They could also detect quaking aspen regeneration on the edges of stands, whereas regeneration in the understory was more difficult to assess. Di Orio et al. (2004) used historic and recent aerial images to study the density and fragmentation of quaking aspen in California over the past 50 years. The accuracy of aerial image interpretation was $85 \%$, 576 the study area. Heyman et al. (2003) mapped quaking aspen in central Oregon from colour-infrared 577 aerial images using a segmentation approach into three general classes (no aspen, minor, predominant) with $88 \%$ overall accuracy. Due to the possibility to fly low-cost and on-demand, UAS 
systems are particularly useful in acquiring data from areas affected by natural or anthropogenic disturbances. Aicardi et al. (2016) performed UAS-based change detection of vegetation after a standreplacing forest fire in northern Italy. Multitemporal high-resolution digital surface models derived from ALS data and RGB imagery provided efficient detection of agamic regeneration of European aspen in the disturbed areas with no aboveground canopy layer.

Advances in imaging spectroscopy have allowed even examination of species genetic variation. Madritch et al. (2014) combined airborne AVIRIS imaging spectroscopy data with genetic, phytochemical, microbial and biogeochemical data to study how genetic variation of quaking aspen influences below-ground processes at landscape-level. Aspen genotypes were discriminated with nearly $80 \%$ accuracy, and the authors suggested that imaging spectroscopy provides a useful tool for mapping aspen genotypes and identifying areas of high or low genetic and chemical diversity in natural forests.

Satellite images enable mapping vegetation dynamics over wide geographical extents. Sankey (2009) detected changes in regional cover of quaking aspen using multispectral Landsat TM5 imagery in a coniferous forest area interspersed with aspen patches in Idaho. The classification was based on summer and fall images and took advantage of aspen phenology compared to the coniferous trees. The overall accuracy of aspen presence/absence classifications was 92-93\%. Using similar satellite data, Sankey (2012) reported that fusing ALS data with the NDVI-based classification improved the overall classification accuracies from $92 \%$ to $96 \%$. Similarly, Bergen and Dronova (2007) identified the extent of aspen-dominated cover type including quaking aspen and bigtooth aspen (Populus grandidentata Michx.) in upper Great Lakes region using Landsat ETM+ leaf-on and leaf-off data with UA and PA of 86-93\%. Chubey et al. (2006) utilised high-resolution panchromatic and multispectral IKONOS imagery in mapping forest stands in Alberta, Canada. Quaking aspen occurred in the region in pure stands and mixed with conifers, and UA and PA for aspen class were $89-100 \%$. Satellite images were also utilised for mapping vegetation health. Oukrop et al. (2011) studied healthy, damaged and seral stand types of quaking aspen to determine the extent of aspen decline in 
605 Utah. The areas with aspen cover were defined from aerial images, and Landsat 5 TM images were 606 utilised to map different aspen classes with an overall accuracy of 81\%. Hall et al. (2014) studied 607 changes in leaf area index (LAI) that resulted from insect defoliation in boreal aspen stands in 608 northern Alberta using Landsat ETM+ images and field data. There was a strong relationship between 609 LAI and the satellite image, and they observed defoliation for the study sites that included relatively 610 pure stands of quaking aspen and balsam poplar (Populus balsamifera L.). Further, Boyd et al. (2019) 611 examined the impact of climate and damage by the aspen epidermal leaf miner (Phyllocnistis 612 populiella) on aspen productivity and physiology in Alaska using remote sensing indices of 613 vegetation productivity (NDVI) acquired from GIMMS3g, MODIS Aqua, MODIS Terra and Landsat $614 \quad 5,7$ and 8.

615 


\begin{tabular}{|c|c|c|c|c|c|c|c|}
\hline & Species & Platform & Data type & $\begin{array}{l}\text { Spectral range } \\
\mu \mathrm{m} \text { (nr of bands) }\end{array}$ & $\begin{array}{l}\text { Pixel size } \\
\mathrm{m}\end{array}$ & $\begin{array}{l}\text { Pulse density } \\
\mathrm{pts} / \mathrm{m}^{2}\end{array}$ & Accuracy estimate \\
\hline \multicolumn{8}{|l|}{ Tree-level } \\
\hline Alonzo et al. (2018) & QA & UAS & PPC, RGB & $B, G, R(3)$ & $0.019-0.027$ & & $U A=83 \%, P A=74 \%$ \\
\hline Breidenbach et al. (2010) & EA & AIR & ALS, MI & $G, R, N I R, P A N(4)$ & $0.275-0.86$ & 7.4 & High RMSE \\
\hline Dalponte et al. 2009 & $\mathrm{PO}$ & AIR & $\mathrm{HI}$ & $0.40-0.99(126)$ & 1 & & $U A=80-90 \%$ \\
\hline Erikson (2004) & EA & AIR & $\mathrm{CIR}$ & $0.60-0.90(3)$ & $0.03-0.1$ & & $U A=63 \%, P A=71 \%$ \\
\hline Franklin and Ahmed (2017) & QA & UAS & MI & $0.49-0.90(6)$ & 0.11 & & $U A \& P A=100 \%$ \\
\hline Jones et al. (2010) & $\mathrm{QA}, \mathrm{PO}$ & AIR & ALS, HI & $0.40-2.50(492)$ & 2 & 0.4 & $U A \& P A<34 \% ; U A=82 \%, P A=98 \%$ \\
\hline Li et al. (2013) & QA & AIR & ALS & & & 90 & $\mathrm{UA}=74 \%, \mathrm{PA}=76 \%$ \\
\hline$\varnothing$ rka et al. (2007) & EA & AIR & ALS & & & 5.09 & $U A=56 \%, P A=24 \%$ \\
\hline Roth et al. (2015a) & $\mathrm{PO}$ & AIR & $\mathrm{HI}$ & $0.35-2.50(224)$ & 4 & & $\mathrm{UA}=84 \%, \mathrm{PA}=87 \%$ \\
\hline Roth et al. (2015b) & $\mathrm{PO}$ & AIR & $\mathrm{HI}$ & $0.35-2.50(224)$ & $4 ; 20 ; 40 ; 60$ & & $U A=83-100 \%, P A=71-96 \%$ \\
\hline Saarinen et al. (2018) & EA & UAS & HI, PPC, RGB & $0.50-0.90(22)$ & $0.10 ; 0.25$ & & High RMSE \\
\hline Säynäjoki et al. (2008) & EA & AIR & ALS, MI & $G, R, N I R, P A N(4)$ & 0.25 & 3.86 & $\mathrm{OA}=79 \%$ \\
\hline Tuominen et al. (2018) & $\mathrm{EA}$ & UAS & HI, PPC, RGB & $0.4-1.60(60)$ & $0.015-0.20$ & & $U A=86 \%, P A=63 \%$ \\
\hline \multicolumn{8}{|l|}{ Stand-level } \\
\hline Aicardi et al. (2016) & EA & UAS, AIR & ALS, RGB & $R, G, B(3)$ & 0.30 & $0.5-10$ & Efficient detection of vegetation dynamics \\
\hline Bergen and Dronova (2007) & $\mathrm{QA}, \mathrm{PO}$ & SAT & $\mathrm{Ml}$ & $0.63-0.90 ; 1.55-1.75(3)$ & 30 & & $\mathrm{UA}=87-93 \%, \mathrm{PA}=86-91 \%$ \\
\hline Boyd et al. 2019 & QA & SAT & $\mathrm{Ml}$ & $0.63-0.90(2)$ & $30 ; 250 ; 0.07^{\circ}$ & & Detection of productivity/physiology changes \\
\hline Chubey et al. 2006 & QA & SAT & $\mathrm{Ml}$ & $0.45-0.85$ / PAN & $1 ; 4$ & & $\mathrm{UA}=100 \%, \mathrm{PA}=89 \%$ \\
\hline Di Orio et al. (2004) & QA & AIR & $\mathrm{Al}$ (n.d.) & n.d. & $\leq 3$ & & $\mathrm{OA}=85 \%$ \\
\hline Hall et al. 2014 & $\mathrm{QA}, \mathrm{PO}$ & SAT & $\mathrm{MI}$ & $0.77-0.90 ; 1.55-1.75(2)$ & 30 & & n.d. \\
\hline Heyman et al. (2003) & QA & AIR & $\mathrm{CIR}$ & $G, R, N I R(3)$ & $1-2$ & & $\mathrm{OA}=88 \%$ \\
\hline Madritch et al. (2014) & QA & AIR & $\mathrm{HI}$ & $0.41-2.45(224)$ & $15-18$ & & $\mathrm{OA}=80 \%$ \\
\hline Oukrop et al. (2011) & QA & AIR, SAT & $\mathrm{CIR}, \mathrm{MI}$ & $\begin{array}{l}G, R, N I R(3) ; 0.45-0.90 ; \\
1.55-1.75 ; 2.08-2.35(6)\end{array}$ & $\begin{array}{l}1 \\
30\end{array}$ & & $\mathrm{OA}=81 \%$ \\
\hline Pippuri et al. (2014) & EA & AIR & ALS, MI & $B, G, N I R, P A N(4)$ & 0.15 & 1.56 & Low compared to dominant species \\
\hline Sankey (2009) & QA & SAT & $\mathrm{MI}$ & $0.52-0.90 ; 1.55-1.75(4)$ & 30 & & $O A=92-93 \%$ \\
\hline Sankey (2012) & QA & AIR; SAT & ALS, MI & $0.52-0.90 ; 1.55-1.75(4)$ & 30 & 5.6 & $O A=92-96 \%$ \\
\hline Strand et al. (2012) & QA & AIR & $\mathrm{CIR}, \mathrm{PAN}, \mathrm{RGB}$ & $\mathrm{B}, \mathrm{G}, \mathrm{R}, \mathrm{NIR}, \mathrm{PAN}$ & $1-2$ & & Visual interpretation \\
\hline
\end{tabular}

Species: $\mathrm{EA}=$ European aspen, $\mathrm{PO}=$ other Populus species, $\mathrm{QA}=$ quaking aspen; Platform: $\mathrm{AIR}=$ aircraft, $\mathrm{SAT}=$ satellite, $\mathrm{UAS}=$ unmanned aerial system; Data type: $\mathrm{Al}=$ aerial imagery, $\mathrm{ALS}=$ airborne laser scanning, $\mathrm{CIR}=$ color-infrared (false-color) imagery, $\mathrm{HI}=$ hyperspectral imagery, $\mathrm{MI}=$ multispectral imagery, $\mathrm{n} . \mathrm{d}$. = no data, $\mathrm{PAN}=$ panchromatic imagery, $P P C=$ photogrammetric point cloud, $R G B=$ red-green-blue (natural color) imagery; Spectral range: $B=$ blue, $G=$ green, $R=$ red, $N I R=$ near-infrared; $A c c u r a c y$ estimate: $\mathrm{OA}=$ overall accuracy, $\mathrm{PA}=$ producer's accuracy, RMSE = root mean square error, UA = user's accuracy 


\section{Discussion and conclusions}

The European aspen has a high conservation value in boreal forests. This feature is due to the large number of species they host compared to the predominant coniferous trees. Our review highlights that the role of aspen as a keystone species in boreal ecosystems has received increasing attention. Negative effects of modern forest management methods and heavy browsing on occurrence, regeneration and long-term persistence of aspen in forest landscapes have been recognised (e.g., Kouki et al., 2004; Edenius et al., 2011). However, there is relatively little spatiotemporal information on the occurrence and distribution of European aspen at local, landscape or regional scales. This deficit can seriously hinder biodiversity assessments and planning, implementation and monitoring of alternative forest management measures, and conservation efforts.

As highlighted by ecological studies, spatially explicit data are needed in order to study aspen abundance, spatial distribution and arrangement, occurrence of large/old trees, long-term occurrence dynamics and aspen regeneration. Forthcoming aspen studies that utilise these data will help us to better understand the current status of different aspen-associated species and their populations and predict their future state. Such information should cover both protected areas-where a great proportion of aspen-related research has already been conducted - as well as managed forests, which characterise the majority of boreal landscape in Europe. In the field of remote sensing, recent developments have provided new opportunities for acquiring more detailed information on the occurrence and distribution of tree species, and characteristics of individual trees and stands (Dalponte et al., 2013; Fassnacht et al., 2018; Beland et al., 2019). This information, alone or in combination with other ecological data, can provide spatially explicit indicators for biodiversity and ecosystem assessments, among other information (Vihervaara et al., 2015; Mononen et al., 2018;

641 Pettorelli et al., 2018).

642 Aspen was mapped with various success by different remote sensing studies reviewed here. In the case of individual tree detection, the major challenges were the low proportion of European aspen in 644 Fennoscandian forest landscapes and the overlap of spectral and/or structural properties of European 
aspen and quaking aspen with other tree species. Due to different research methods and various tree species composition, comparison of different studies is not straightforward. However, the results suggest that especially three-dimensional structural information derived from high-density ALS data or photogrammetric point clouds, and airborne imaging spectroscopy, hold significant potential for tree species mapping (Dalponte et al., 2009; Jones et al., 2010; Li et al., 2013; Roth et al., 2015b; Alonzo et al., 2018). The studies also indicate that combining spectral data with three-dimensional data can noticeably improve species detection at the individual tree level and stand level. Thus, remote sensing with repeated monitoring should be utilized to fulfill the current need of studies on landscape dynamics considering rotation lengths, succession and persistence of key species.

In addition to species discrimination, remote sensing can provide information on biophysical and biochemical properties of vegetation (Roberts et al., 2004). For example, knowledge about individual tree properties, including tree height, crown dimensions and biomass, can help predict the potential occurrence and distribution of species often associated with large/old aspen trees. Mapping aspen regeneration is difficult except in post-disturbance areas without dense canopy cover (see Aicardi et observations enable detection of major disturbances on aspen populations caused by insect herbivory, pathogens or drought, among others (Oukrop et al., 2011; Hall et al., 2013). Furthermore, recent research indicates that imaging spectroscopy data are suitable for mapping species genotypes and for identifying areas of high or low genetic diversity (Madritch et al., (2014). Yamasaki et al. (2018) recommend that future research that combines genomics with remote sensing could help monitoring and predicting ecosystem dynamics. These findings will be particularly interesting to better understand aspen's role in boreal ecosystems.

Suitability of remote sensing data for biodiversity mapping and monitoring is also determined by geographical coverage, availability of multitemporal data and costs of data acquisition. For example, high-resolution hyperspectral and three-dimensional structural data can be acquired on-demand using 
671 data acquisition by plane over larger areas (landscape scale) is typically conducted by service 672 providers (Beland et al., 2019). Although hyperspectral and lidar airborne sensors have developed a 673 lot over the past years, the data prices remain relatively high compared to traditional aerial and 674 multispectral satellite images. This factor prevents more extensive exploitation of the data. Several 675 spaceborne imaging spectrometers are currently under development; they should provide for the first 676 time global coverage of hyperspectral data for vegetation mapping, although in coarser resolution 677 compared to airborne data (Lee et al., 2015; Roth et al., 2015b). An important feature of spaceborne 678 data is the continual availability of multitemporal and seasonal data. Utilising seasonal spectral data 679 enables monitoring vegetation dynamics, provides valuable information for species detection and 680 improve tree species classifications, as indicated by the reviewed studies. Furthermore, a recently 681 developed multispectral laser scanning technique, which provides a dense point cloud together with 682 spectral information, may have significant potential in tree species detection in the future (Yu et al., 683 2017; Budei et al., 2018; Beland et al., 2019).

684 Currently, increasing spatial, spectral and temporal resolutions - and the availability of three685 dimensional data - have brought remote sensing research closer to the scales of ecological research. 686 Communication between experts in different research fields can foster innovations, generate new 687 research directions and accelerate the development of new remote sensing products suitable for 688 mapping different ecological features or biodiversity indicators (Pettorelli et al., 2018; Wang \& 689 Gamon 2019). In the case of aspen in boreal forests, or any other key ecological feature, collaboration 690 between the disciplines of ecology, conservation science and remote sensing will improve the 691 potential for remote sensing data to support biodiversity monitoring and management. Integration of 692 ecological datasets with remote sensing data describing aspen occurrence and characteristics is a key 693 for understanding the current and future distribution patterns of aspen-related biodiversity. 


\section{Acknowledgements}

697 This study was funded by the project 'The Integrated Biodiversity Conservation and Carbon 698 Sequestration in the Changing Environment' (IBC-Carbon, project number 312559), Strategic 699 Research Council, Academy of Finland.

\section{References}

702

Aicardi, I., Garbarino, M., Lingua, A., Lingua, E., Marzano, R., \& Piras, M. 2016. Monitoring PostFire Forest Recovery Using Multitemporal Digital Surface Models Generated from Different Platforms. Earsel Eproceedings, 15, 1-8.

Alchanatis, V., Cohen, Y. 2012. Spectral and spatial methods of hyperspectral image analysis for estimation of biophysical and biochemical properties of agricultural crops. Hyperspectral Remote Sensing of Vegetation 19, 289-308.

Alonzo, M., Andersen, H. E., Morton, D.C. \& Cook, B.D. 2018. Quantifying boreal forest structure and composition using UAV structure from motion. Forests 9, 119.

Ampoorter, E., Barbaro, L., Jactel, H., Baeten, L., Boberg, J., Carnol, M., ... \& Smedt, P. D. 2019. Tree diversity is key for promoting the diversity and abundance of forest-associated taxa in Europe. Oikos 129, 133-146.

Angelstam, P., Mikusiński, G., 1994. Woodpecker assemblages in natural and managed boreal and hemiboreal forest — a review. Annales Zoologici Fennici 31, 157-172. http://www.jstor.org/stable/23735508

Baroni, D., Korpimäki, E., Selonen, V., \& Laaksonen, T. 2020. Tree cavity abundance and beyond: Nesting and food storing sites of the pygmy owl in managed boreal forests. Forest Ecology and Management 460, 117818.

Beland, M., Parker, G., Sparrow, B., Harding, D., Chasmer, L., Phinn, S., ... \& Strahler, A. 2019. On promoting the use of lidar systems in forest ecosystem research. Forest Ecology and Management $450,117484$. 
Bergen, K. M., Dronova, I. 2007. Observing succession on aspen-dominated landscapes using a remote sensing-ecosystem approach. Landscape Ecology 22, 1395-1410.

Bergeron, Y., Chen, H. Y., Kenkel, N. C., Leduc, A. L., \& Macdonald, S. E. 2014. Boreal mixedwood stand dynamics: ecological processes underlying multiple pathways. The Forestry Chronicle 90, 202-213.

Boyd, M. A., Berner, L. T., Doak, P., Goetz, S., Rogers, B., Wagner, D., ... \& Mack, M. C. 2019. Impacts of climate and insect herbivory on productivity and physiology of trembling aspen (Populus tremuloides) in Alaskan boreal forests. Environmental Research Letters 14, 085010.

Breidenbach, J., Næsset, E., Lien, V., Gobakken, T. \& Solberg, S. 2010. Prediction of species specific forest inventory attributes using a nonparametric semi-individual tree crown approach based on fused airborne laser scanning and multispectral data. Remote Sensing of Environment, 114, 911924.

Brockerhoff, E. G., Barbaro, L., Castagneyrol, B., Forrester, D. I., Gardiner, B., González-Olabarria, J. R., ... \& Thompson, I. D. 2017. Forest biodiversity, ecosystem functioning and the provision of ecosystem services. Biodiversity and Conservation 26, 3005-3035

Buck JR, St. Clair SB 2012. Aspen increase soil moisture, nutrients, organic matter and respiration in Rocky Mountain forest communities. PLoSONE 7, e52369. doi:10.1371/journal.pone.0052369

Budei, B. C., St-Onge, B., Hopkinson, C., Audet, F. A. 2018. Identifying the genus or species of individual trees using a three-wavelength airborne lidar system. Remote Sensing of Environment 204, 632-647.

Callan, B.E. ,1998. Diseases of Populus in British Columbia: a Diagnostic Manual. Natural Resources Canada, Canadian Forest Service, Pacific Forestry Centre, Victoria, British Columbia, Canada.

Caudullo, G., de Rigo, D. 2016. Populus tremula in Europe: distribution, habitat, usage and threats. European Atlas of Forest Tree Species. Publ. Off. EU, Luxembourg, pp. e01f148. 
Chubey, M. S., Franklin, S. E., \& Wulder, M. A. 2006. Object-based analysis of Ikonos-2 imagery for extraction of forest inventory parameters. Photogrammetric Engineering \& Remote Sensing, 72, 383-394.

Clawges, R., Vierling, K., Vierling, L. \& Rowell, E. 2008. The use of airborne lidar to assess avian species diversity, density, and occurrence in a pine/aspen forest. Remote Sensing of Environment 112, 2064-2073.

Colomina, I., Molina, P. 2014. Unmanned aerial systems for photogrammetry and remote sensing: A review. ISPRS Journal of Photogrammetry and Remote Sensing, 92, 79-97.

Dahlberg, A., Stokland J.N. 2004. Vedlevande arters krav på substrat - sammanställning och analys av 3600 arter. Skogsstyrelsen, Rapport 7

Dalponte, M., Bruzzone, L., Vescovo, L., \& Gianelle, D. (2009). The role of spectral resolution and classifier complexity in the analysis of hyperspectral images of forest areas. Remote Sensing of Environment 113, 2345-2355.

Dalponte, M., Økra, H.O., Gobakken, T., Gianelle, D., \& Næsset, E. 2013. Tree species classification in boreal forests with hyperspectral data. IEEE Transactions on Geoscience and Remote Sensing 51, 2632-2645. doi:10.1109/TGRS.2012.2216272

de Chantal, M., Granström, A. 2007. Aggregations of dead wood after wildfire act as browsing refugia for seedlings of Populus tremula and Salix caprea. Forest Ecology and Management 250, 3-8.

DeWoody, J., Rowe, C.A., Hipkins, V.D., Mock, K.E. 2008. "Pando" lives: molecular genetic evidence of a giant aspen clone in central Utah. Western North American Naturalist 68, 493-497.

Di Orio, A.P., Callas, R., Schaefer, R. J. 2005. Forty-eight year decline and fragmentation of aspen (Populus tremuloides) in the South Warner Mountains of California. Forest Ecology and Management 206, 307-313.

Easton, E., 1997. Genetic variation and conservation of the native aspen (Populus tremula L.) resource in Scotland. PhD Thesis, University of Edinburgh, UK. 
Edenius, L., Eriksson, G. 2007. Aspen demographics in relations to spatial context and ungulate browsing: Implications for conservation and forest management. Biological Conservation 135, 293-301.

Edenius, L., Ericsson, G., Kempe, G., Bergström, R. \& Danell, K. 2011. The effects of changing land use and browsing on aspen abundance and regeneration: a 50-year perspective from Sweden. Journal of Applied Ecology 48, 301-309.

Edenius, L., Ericsson, G. 2015. Effects of ungulate browsing on recruitment of aspen and rowan: a demographic approach. Scandinavian Journal of Forest Research 30, 283-288.

Erikson, M. 2004. Species classification of individually segmented tree crowns in high-resolution aerial images using radiometric and morphologic image measures. Remote Sensing of Environment 91, 469-477.

Esseen, P.A., Ehnström, B., Ericson, L., \& Sjöberg, K. 1997. Boreal forests. Ecological Bulletins 46, $16-47$.

Fassnacht, F. E., Latifi, H., Stereńczak, K., Modzelewska, A., Lefsky, M., Waser, L. T., ... \& Ghosh, A. 2016. Review of studies on tree species classification from remotely sensed data. Remote Sensing of Environment 186, 64-87.

Féret, J-B, Asner, G.P. 2013. Tree Species Discrimination in Tropical Forests Using Airborne Imaging Spectroscopy. IEEE Transactions on Geoscience and Remote Sensing 51, 73

Fedrowitz, K., Koricheva, J., Baker, S., Lindenmayer, D., Palik, B., Rosenvald, R., Beese, W., Franklin, J., Kouki, J., Macdonald, E., Messier, C., Sverdrup-Thygeson, A. \& Gustafsson, L. 2014. Can retention forestry help conserve biodiversity? A meta-analysis. Journal of Applied Ecology 51, 1660-1679. http://dx.doi.org/10.1111/1365-2664.12289

Filipescu, C. N., Comeau, P. G. 2007. Aspen competition affects light and white spruce growth across several boreal sites in western Canada. Canadian Journal of Forest Research 37, 1701-1713.

Franklin, S. E. 2018. Pixel-and object-based multispectral classification of forest tree species from small unmanned aerial vehicles. Journal of Unmanned Vehicle Systems 6, 195-211. 
Franklin, S. E. \& Ahmed, O. S. 2018. Deciduous tree species classification using object-based analysis and machine learning with unmanned aerial vehicle multispectral data. International Journal of Remote Sensing 39, 5236-5245.

801 Fraser, E. C., Landhäusser, S. M., \& Lieffers, V. J. 2003. The effects of mechanical site preparation

Haara, A., Haarala, M. 2002. Tree species classification using semi-automatic delineation of trees on aerial images. Scandinavian Journal of Forest Research 17, 556-565. 
Hågvar, S., Hågvar, G. Mønness, E. 1990. Nest site selection in Norwegian woodpeckers. Holarctic Ecology 13, 156-165.

Hall, R.J., Fernandes, R.A., Hogg, E.H., Brandt, J.P., Butson, C., Case, B.S., LeBlanc, G.S. 2003. Relating aspen defoliation to changes in leaf area derived from field and satellite remote sensing data. Can. J. Remote Sensing 29, 299-313.

Halme, P., Vartija, N., Salmela, J., Penttinen, J. Norros, V. 2013. High within- and between-trunk variation in the nematoceran (Diptera) community and its physical environment in decaying aspen trunks. Insect Conservation and Diversity 6, 502-512.

Hämäläinen, A., Hujo, M., Heikkala, O., Junninen, K., \& Kouki, J. 2016. Retention tree characteristics have major influence on the post-harvest tree mortality and availability of coarse woody debris in clear-cut areas. Forest Ecology and Management 369, 66-73.

Hämäläinen, K., Junninen, K., Halme, P. \& Kouki, J. 2020. Managing conservation values of protected sites: How to maintain deciduous trees in white-backed woodpecker territories. Forest Ecology and Management 461, 117946.

Hanski, I.K., 1998. Home ranges and habitat use in the declining flying squirrel Pteromys volans in managed forests. Wildlife Biology 4, 33-46.

Hardenbol, A. A., Pakkala, T., \& Kouki, J. 2019. Persistence of a keystone microhabitat in boreal forests: Cavities of Eurasian Three-toed Woodpeckers (Picoides tridactylus). Forest Ecology and Management 450, 117530.

Hazell, P., Kellner, O., Rydin, H., Gustafsson, L. 1998. Presence and abundance of four epiphytic bryophytes in relation to density of aspen Populus tremula and other stand characteristics. Forest Ecology and Management 107, 147-158.

Hedenås, H. \& Ericson, L. 2000. Epiphytic macrolichens as conservation indicators: successional sequence in Populus tremula stands. Biol. Conserv. 93, 43-53.

Hedenås, H., Blomberg, P., and Ericson, L., 2007. Significance of old aspen (Populus tremula) trees for the occurrence of lichen photobionts. Biological Conservation 135, 380-387. 
Hedenås, H., Hedström, P. 2007. Conservation of epiphytic lichens: Significance of remnant aspen (Populus tremula) trees in clear-cuts. Biological Conservation 135, 388-395.

Heyman, O., Gaston, G.G., Kimerling, A.J. \& Campbell, J.T. 2003. A per-segment approach to improving aspen mapping from high-resolution remote sensing imagery. Journal of Forestry, 101, 29-33.

Hirschmuller, H., 2008. Stereo processing by semi-global matching and mutual Information. IEEE Transactions on Pattern Analysis and Machine Intelligence 30, 328-341.

Hjältén, J., Danell, K., Ericson, L. 2004. Hare and vole browsing preferences during winter. Acta Theriologica 49, 53-62.

Holmgren, J., Persson, Å., Söderman, U. 2008. Species identification of individual trees by combining high resolution LiDAR data with multi-spectral images. International Journal of Remote Sensing 29, 1537-1552.

Hooper, D.U., Adair, E.C., Cardinale, B.J., Byrnes, J.E., Hungate, B.A., Matulich, K.L., Gonzalez, A., Duffy, J.E., Gamfeldt, L. \& O’Connor, M.I., 2012. A global synthesis reveals biodiversity loss as a major driver of ecosystem change. Nature 486, 105. doi:10.1038/nature11118

Hynynen, J. \& Viherä-Aarnio, A. (eds.) 1999. Haapa - monimuotoisuutta metsään ja metsätalouteen. Metsäntutkimuslaitoksen tiedonantoja 725.

Hyvärinen, E., Juslén, A., Kemppainen, E., Uddström, A., \& Liukko, U. M. (2019). Suomen lajien uhanalaisuus-Punainen kirja 2019.

IPBES (2019). IPBES Global Assessment Summary for Policymakers. The Intergovernmental Science-Policy Platform on Biodiversity and Ecosystem Services. https://www.ipbes.net/news/ipbes-global-assessment-summary-policymakers-pdf

IPCC (2018). Global Warming of $1.5^{\circ}$ C: An IPCC Special Report on the Impacts of Global Warming of $1.5^{\circ}$ C Above Pre-industrial Levels and Related Global Greenhouse Gas Emission Pathways, in the Context of Strengthening the Global Response to the Threat of Climate Change, Sustainable Development, and Efforts to Eradicate Poverty. Intergovernmental Panel on Climate Change. 
Jacobsen et al. 2015. Scale-specific responses of saproxylic beetles: combining dead wood surveys with data from satellite imagery. J Insect Conserv 19, 1053-1062.

Johnson, S., Strengbom, J., Kouki, J. 2014. Low levels of tree retention do not mitigate the effects of clearcutting on ground vegetation dynamics. Forest Ecology and Management 330, 67-74.

Jones, T. G., Coops, N. C. \& Sharma, T. 2010. Assessing the utility of airborne hyperspectral and LiDAR data for species distribution mapping in the coastal Pacific Northwest, Canada. Remote Sensing of Environment 114, 2841-2852.

Jonsell, M., Weslien, J., Ehnström, B. 1998. Substrate requirements of red-listed saproxylic invertebrates in Sweden. Biodiversity \& Conservation 7, 749-764.

Jönsson, M. T., Fraver, S., Jonsson, B. G., Dynesius, M., Rydgård, M., \& Esseen, P. A. 2007. Eighteen years of tree mortality and structural change in an experimentally fragmented Norway spruce forest. Forest Ecology and Management 242, 306-313.

Junninen, K., Penttilä, R., Martikainen, P. 2007. Fallen retention aspen trees on clear-cuts can be important habitats for red-listed polypores: a case study in Finland. Biodiversity and Conservation $162,475-490$.

Kasanen, R., Hantula, J., Vuorinen, M., Stenlid, J., Solheim, H. Kurkela, T. 2004. Migrational capacity of Fennoscandian populations of Venturia tremulae. Mycol. Res. 108, 64-70.

Kangas A. 2006. Sampling rare populations. In: Forest Inventory. Springer, Dordrecht, 2006. p. 119139.

Kay, C. E. 1997. Is aspen doomed? Journal of Forestry 95, 4-11.

Koivula, M., Punttila, P., Haila, Y. \& Niemelä, J. 1999. Leaf litter and the small-scale distribution of carabid beetles (Coleoptera, Carabidae) in the boreal forest. Ecography 22, 424-435.

Kolström, M., Lumatjärvi, J. 2000. Saproxylic beetles on aspen in commercial forests: a simulation approach to species richness. Forest Ecology and Management 126, 113-120. 
900 Komonen, A., Tuominen, L., Purhonen, J., \& Halme, P. 2020. Landscape structure influences 901 browsing on a keystone tree species in conservation areas. Forest Ecology and Management 457, $902 \quad 117724$.

903 Korpela, I., Ørka, H. O., Maltamo, M., Tokola, T. \& Hyyppä, J. 2010. Tree species classification 904 using airborne LiDAR-effects of stand and tree parameters, downsizing of training set, intensity 905 normalization, and sensor type. Silva Fennica 44, 319-339.

906 Kotiranta, H., Niemelä, T., 1981. Composition of the polypore communities of four forest areas in $907 \quad$ southern Central Finland. Karstenia 21, 31-48.

908 Kouki, J., Arnold, K. \& Martikainen, P. 2004. Long-term persistence of aspen-a key host for many 909 threatened species-is endangered in old-growth conservation areas in Finland. Journal for Nature 910 Conservation 12, 41-52.

911 Kuuluvainen, T., Lindberg, H., Vanha-Majamaa, I., Keto-Tokoi, P., \& Punttila, P. 2019. Low-level 912 retention forestry, certification, and biodiversity: case Finland. Ecological Processes 8, 47.

913 Kuusinen 1994. Epiphytic lichen flora and diversity on Populus tremula in old-growth and managed 914 forests of southern and middle boreal Finland. Annales Botanici Fennici 31, 245-260.

915 Landhäusser, S.M., Pinno, B.D., Mock, K.E. 2019. Tamm Review: Seedling-based ecology, 916 management, and restoration in aspen (Populus tremuloides). Forest Ecology and Management $917 \quad 432,231-245$.

918 Lankia, H., Wallenius, T., Várkonyi, G., Kouki, J., Snäll, T. 2012. Forest fire history, aspen and goat 919 willow in a Fennoscandian old-growth landscape: are current population structures a legacy of 920 historical fires? Journal of Vegetation Science 23, 1159-1169.

921 Latva-Karjanmaa, T., Suvanto, L., Leinonen, K., Rita, H. 2003. Emergence and survival of Populus 922 tremula seedlings under varying moisture conditions. Canadian Journal of Forest Research 33, $923 \quad 2081-2088$. 
Latva-Karjanmaa, T., Penttilä, R., Siitonen, J. 2007. The demographic structure of European aspen (Populus tremula) populations in managed and old-growth boreal forests in eastern Finland. Canadian Journal of Forest Research 37, 1070-1081.

Lavsund, S., Nygrén, T. \& Solberg, E. J. 2003. Status of moose populations and challenges to moose management in Fennoscandia. Alces 39, 30.

Lee, C. M., Cable, M. L., Hook, S. J., Green, R. O., Ustin, S. L., Mandl, D. J., Middleton, E. M. 2015. An introduction to the NASA Hyperspectral InfraRed Imager (HyspIRI) mission and preparatory activities Remote Sensing of Environment 167, 6-19.

Li, J., Hu, B. \& Noland, T.L. 2013. Classification of tree species based on structural features derived from high density LiDAR data. Agricultural and Forest Meteorology 171, 104-114.

Lilja, S., Wallenius, T. \& Kuuluvainen, T. 2006. Structure and development of old Picea abies forests in northern boreal Fennoscandia. Ecoscience 13, 181-192.

Lundström, J., Jonsson, F., Perhans, K., Gustafsson, L. 2013. Lichen species richness on retained aspens increases with time since clear-cutting. Forest Ecology and Management 293, 49-56.

MacKenzie, N.A. 2010. Ecology, conservation and management of Aspen. A literature review. Scottish Native Woods, Aberfeldy.

Madritch, M.D., Kingdon, C.C., Singh, A., Mock, K.E., Lindroth, R.L. \& Townsend, P.A. 2014. Imaging spectroscopy links aspen genotype with below-ground processes at landscape scales. Philosophical Transactions of the Royal Society of London B: Biological Sciences 369, 20130194.

Maltamo M., Packalen P. 2014. Species specific management inventory in Finland. In: Maltamo M., Naesset E., Vauhkonen J. (eds.). Forestry applications of airborne laser scanning - concepts and case studies. Managing Forest Ecosystems vol. 27, Springer. p. 241-252. http://dx.doi. org/10.1007/978-94-017-8663-8_12.

Maltamo, M., Pesonen, A., Korhonen, L., Kouki, J., Vehmas, M. \& Eerikäinen, K. 2015. Inventory of aspen trees in spruce dominated stands in conservation area. Forest Ecosystems 2, 12. 
Maltamo, M., Karjalainen, T., Repola, J. \& Vauhkonen, J. 2018. Incorporating tree-and stand-level information on crown base height into multivariate forest management inventories based on airborne laser scanning. Silva Fennica 52, 10006. 10.14214/sf.10006.

Martikainen, P, Penttilä, R, Kotiranta, H \& Miettinen, O. 2000. New records of Funalia trogii, Perenniporia tenuis and Polyporus pseudobetulinus from Finland, with notes on their habitat requirements and conservation implications. Karstenia 40, 79-92.

Martikainen, P. 2001. Conservation of threatened saproxylic beetles: significance of retained aspen Populus tremula on clearcut areas. Ecological Bulletins 49, 205-218.

Martin, K., Eadie, J.M. 1999. Nest webs: A community-wide approach to the management and conservation of cavity-nesting forest birds. Forest Ecology and Management 115, 243-257.

Mazziotta, A., Triviño, M., Tikkanen, O. P., Kouki, J., Strandman, H., \& Mönkkönen, M. 2016. Habitat associations drive species vulnerability to climate change in boreal forests. Climatic Change 135(3-4), 585-595.

McRoberts, R. E., Tomppo, E. O. 2007. Remote sensing support for national forest inventories. Remote Sensing of Environment 110(4), 412-419.

Michaelsen, T.C. 2016. Aspen Populus tremula is a key habitat for tree-dwelling bats in boreonemoral and south boreal woodlands in Norway. Scandinavian Journal of Forest Research $31,477-483$.

Mock, K. E., Rowe, C. A., Hooten, M. B., Dewoody, J., Hipkins, V.D. 2008. Clonal dynamics in western North American aspen (Populus tremuloides). Molecular Ecology 17, 4827-4844.

Mönkkönen, M., Burgas, D., Eyvindson, K., Le Tortorec, E., Peura, M., Pohjanmies, T., ... \& Triviño, M. 2018. Solving conflicts among conservation, economic, and social objectives in boreal production forest landscapes: Fennoscandian perspectives. In Ecosystem Services from Forest Landscapes (pp. 169-219). Springer, Cham.

Mononen, L., Auvinen, A.-P., Packalen, P., Virkkala, R., Valbuena, R., Bohlin, I., Valkama, J. \& Vihervaara, P. 2018: Usability of citizen science observations together with airborne laser 
scanning data in determining the habitat preferences of forest birds. Forest Ecology and Management 430, 498-508.

Myking, T., Bøhler, F., Austrheim, G., \& Solberg, E. J. 2011. Life history strategies of aspen (Populus tremula L.) and browsing effects: a literature review. Forestry 84, 61-71.

Naidoo, L., Cho, M.A., Mathieu, R., Asner, G., 2012. Classification of savanna tree species, in the 980 Greater Kruger National Park region, by integrating hyperspectral and LiDAR data in a Random $981 \quad$ Forest data mining environment. ISPRS J. Photogramm., 69, 167-179.

982 Næsset, E. 2007. Airborne laser scanning as a method in operational forest inventory: status of 983 accuracy assessments accomplished in Scandinavia. Scand J For Res 22, 433-442

984 Næsset, E. 2009. Effects of different sensors, flying altitudes, and pulse repetition frequencies on 985 forest canopy metrics and biophysical stand properties derived from small-footprint airborne laser 986 data. Remote Sensing of Environment 113, 148-159.

987 Nikula, S., Vapaavuori, E., Manninen, S. 2010. Urbanization-related changes in European aspen 988 (Populus tremula L.): leaf traits and litter decomposition. Environmental Pollution 158(6), 21329892142.

990 Økland, B., Bakke, A., Hågvar, S., Kvamme, T., 1996. What factors influence the diversity of 991 saproxylic beetles - a multiscaled study from a spruce forest in southern Norway. Biodiversity 992 and Conservation 5, 75-100.

993 Oldén, A., Ovaskainen, O., Kotiaho, J. S., Laaka-Lindberg, S. \& Halme, P. 2014. Bryophyte species 994 richness on retention aspens recovers in time but community structure does not. PloS one 9, 995 e93786.

996 Ørka, H. O., Næsset, E. \& Bollandsås, O. M. 2007. Utilizing airborne laser intensity for tree species 997 classification. International Archives of the Photogrammetry, Remote Sensing and Spatial 998 Information Sciences 36, W52. 
Ørka, H. O., Næsset, E. \& Bollandsås, O. M., 2010. Effects of different sensors and leaf-on and leaf1000 off canopy conditions on echo distributions and individual tree properties derived from airborne 1001 laser scanning. Remote Sensing of Environment 114, 1445-1461.

1002 Östlund, L., Zackrisson, O., Axelsson, A. L. 1997. The history and transformation of a Scandinavian 1003 boreal forest landscape since the 19th century. Canadian Journal of Forest Research 27, 1198$1004 \quad 1206$.

1005 Oukrop, C.M., Evans, D.M., Bartos, D.L., Ramsey, R.D. \& Ryel, R.J. 2011. Moderate-scale mapping 1006 methods of aspen stand types: a case study for Cedar Mountain in southern Utah. Gen. Tech. Rep. 1007 RMRS-GTR-259. Fort Collins, CO: US Department of Agriculture, Forest Service, Rocky 1008 Mountain Research Station. 18 p., 259.

1009 Packalén, P., Maltamo, M., 2007. The k-MSN method for the prediction of species-specific stand 1010 attributes using airborne laser scanning and aerial photographs. Remote Sensing of Environment $1011 \quad 109,328-341$.

1012 Perhans, K., Haight, R.G., Gustafsson, L. 2014. The value of information in conservation planning: 1013 selecting retention trees for lichen conservation. Forest Ecology and Management 318, 175-182. 1014 Persson, Å., Holmgren, J., Söderman, U., Olsson, H., 2004. Tree species classification of individual 1015 trees in sweden by combining high resolution laser data with high resolution near infrared digital 1016 images. Proceedings of the Natscan Conference, 4-6 Oct. 2004.

1017 Pettorelli, N., Safi, K., \& Turner, W. 2014. Satellite remote sensing, biodiversity research and 1018 conservation of the future. 20130190.

1019 Piiroinen, R., Heiskanen, J., Maeda, E., Viinikka, A., Pellikka, P. 2017. Classification of tree species 1020 in a diverse African agroforestry landscape using imaging spectroscopy and laser scanning. $1021 \quad$ Remote Sensing 9, 1-20.

1022 Pippuri, I., Maltamo, M., Packalen, P., Mäkitalo, J. 2013. Predicting species-specific basal areas in 1023 urban forests using airborne laser scanning data and existing stand register data. Eur J For Res $1024 \quad 132,999-1012$. 
Possen, B.J.H.M., Oksanen, E., Rousi, M., Ruhanen, H., Ahonen, V., Tervahauta, A., Heinonen, J., Heiskanen, J., Kärenlampi, S., Vapaavuori, E. 2011. Adaptability of birch (Betula pendula Roth) and aspen (Populus tremula L.) genotypes to different soil moisture conditions. Forest Ecology and Management 262, 1387-1399.

Prisley, S. P., Smith, J. L. 1987. Using classification error matrices to improve the accuracy of weighted land-cover models. Photogrammetric engineering and remote sensing 53(9), 1259-1263

Puliti, S., Ørka, H.O., Gobakken, T., Næsset, E. 2015. Inventory of small forest areas using an unmanned aerial system. Remote Sensing 7, 9632-9654.

Pykälä, J., Heikkinen, R. K., Toivonen, H., \& Jääskeläinen, K. 2006. Importance of Forest Act habitats for epiphytic lichens in Finnish managed forests. Forest Ecology and Management 223, 84-92.

Ranius, T., Martikainen, P., Kouki, J. 2011. Colonisation of ephemeral forest habitats by specialized species: beetles and bugs associated with recently dead aspen wood. Biodivers Conserv 20, $2903-$ 2915.

Rassi, P., Hyvärinen, E., Juslén, A. \& Mannerkoski, I. 2010. The 2010 Red List of Finnish species. Ympäristöministeriö \& Suomen ympäristökeskus, Helsinki, 685.

Remm, J., Hanski, I. K., Tuominen, S., \& Selonen, V. 2017. Multilevel landscape utilization of the Siberian flying squirrel: Scale effects on species habitat use. Ecology and evolution 7, 83038315.

Reinikainen, M., D’Amato, A. W., \& Fraver, S. 2012. Repeated insect outbreaks promote multicohort aspen mixedwood forests in northern Minnesota, USA. Forest Ecology and Management, 266, 148-159.

Rhodes, A. C., Wan, H. Y., Clair, S. B. S. 2017. Herbivory impacts of elk, deer and cattle on aspen forest recruitment along gradients of stand composition, topography and climate. Forest Ecology and Management 397, 39-47. 
1050

1051

1052

1053

1054

1055

1056

1057

1058

1059

1060

1061

1062

1063

1064

Robinson, K.M. Ingvarsson, P.K., Jansson, S., Albrectsen, B.R. 2012. Genetic variation in functional traits influences arthropod community composition in aspen (Populus tremula L.) PLos One 7, e37679.

Rodríguez, A., Pohjoismäki, J. L., \& Kouki, J. 2019. Diversity of forest management promotes parasitoid functional diversity in boreal forests. Biological Conservation 238, 108205.

Rogers, P. C., Pinno, B. D., Šebesta, J., Albrectsen, B. R., Li, G., Ivanova, N., .. \& Myking, T. 2019. A global view of aspen: Conservation science for widespread keystone systems. Global Ecology and Conservation, e00828.

Roth, K. L., Roberts, D. A., Dennison, P. E., Alonzo, M., Peterson, S. H., \& Beland, M. (2015a). Differentiating plant species within and across diverse ecosystems with imaging spectroscopy. Remote Sensing of Environment 167, 135-151.

Roth, K. L., Roberts, D. A., Dennison, P. E., Peterson, S. H., \& Alonzo, M. (2015b). The impact of spatial resolution on the classification of plant species and functional types within imaging spectrometer data. Remote Sensing of Environment 171, 45-57.

Rosenvald, R., Lohmus, A. 2008. For what, when, and where is green-tree retention better than clearcutting? A review of the biodiversity aspects. Forest Ecology and Management 255, 1-15.

Rosenvald, R., Lohmus, A., \& Kiviste, A. 2008. Preadaptation and spatial effects on retention-tree survival in cut areas in Estonia. Canadian Journal of Forest Research 38, 2616-2625.

Rosenvald, R., Lõhmus, P., Rannap, R., Remm, L., Rosenvald, K., Runnel, K., \& Lõhmus, A. 2019. Assessing long-term effectiveness of green-tree retention. Forest Ecology and Management 448, $543-548$.

Rouvinen, S., Rautiainen, A. \& Kouki, J. 2005. A relation between historical forest use and current dead woody material in a boreal protected old-growth forest in Finland. Silva Fennica 39, 21-36.

Runnel, K., Rosenvald, R., \& Lõhmus, A. 2013. The dying legacy of green-tree retention: different habitat values for polypores and wood-inhabiting lichens. Biological Conservation 159, 187-196. 
1075 Saarinen, N., Vastaranta, M., Näsi, R., Rosnell, T., Hakala, T., Honkavaara, E., Wulder, M.A., 1076 Luoma, V., Tommaselli, A.M.G., Imai, N.N., Ribeiro, E.A.W., Guimaraes, R.B., Holopainen, M. 1077 \& Hyyppä, J. 2018. Assessing Biodiversity in Boreal Forests with UAV-Based Photogrammetric $1078 \quad$ Point Clouds and Hyperspectral Imaging. Remote Sensing 10, 338.

1079 Sahlin, E., Ranius, T., 2009. Habitat availability in forests and clearcuts for saproxylic beetles $1080 \quad$ associated with aspen. Biodiversity and Conservation 18, 621.

1081 Sankey, T.T. 2009. Regional assessment of aspen change and spatial variability on decadal time 1082 scales. Remote Sensing 1, 896-914.

1083 Sankey, T.T. 2012. Decadal-scale aspen changes: evidence in remote sensing and tree ring data. 1084 Applied Vegetation Science 15,

1085 Schei, F. H., Blom, H. H., Gjerde, I., Grytnes, J. A., Heegaard, E. \& Sætersdal, M. 2013. Conservation 1086 of epiphytes: Single large or several small host trees? Biological Conservation 168, 144-151.

1087 Seager, S.T., Eisenberg, C., St. Clair, S.B., 2013. Patterns and consequences of ungulate herbivory 1088 on aspen in western North America. Forest Ecology and Management 299, 81-90.

1089 Seedre, M., Felton, A., \& Lindbladh, M. 2018. What is the impact of continuous cover forestry 1090 compared to clearcut forestry on stand-level biodiversity in boreal and temperate forests? A $1091 \quad$ systematic review protocol. Environmental Evidence 7, 28.

1092 Siitonen, J., Martikainen, P. 1994. Occurrence of rare and threatened insects living on decaying 1093 Populus tremula: a comparison between Finnish and Russian Karelia. Scandinavian Journal of 1094 Forest Research 9, 185-19. https://doi.org/10.1080/02827589409382830

1095 Singer, J. A., Turnbull, R., Foster, M., Bettigole, C., Frey, B. R., Downey, M. C., ... \& Ashton, M. S. 1096 2019. Sudden Aspen Decline: A review of pattern and process in a changing climate. Forests 10, $1097 \quad 671$.

1098 Sivadasan, U., Chenhao, C., Nissinen, K., Randriamanana, T., Nybakken, L., Julkunen-Tiitto, R. 1099 Growth and defence of aspen (Populus tremula) after three seasons under elevated temperature 1100 and ultraviolet-B radiation. Can. J. For. Res. 48, 629-641 
1101 St-Onge, B., Vega, C., Fournier, R. A., Hu, Y. 2008. Mapping canopy height using a combination of 1102 digital stereo-photogrammetry and lidar. International Journal of Remote Sensing 29, 3343-3364. 1103 Strand, E.K., O'Sullivan, M.T. \& Bunting, S.C. 2012. Time series aerial photography can help land 1104 owners and managers understand local aspen dynamics. Rangelands 34, 21-29.

1105 Suominen, O., Edenius, L., Ericsson, G. \& de Dios, V.R. 2003. Gastropod diversity in aspen stands 1106 in coastal northern Sweden. Forest Ecology and Management 175, 403-412.

1107 Suvanto, L.I., Latva-Karjanmaa, T.B. 2005. Clone identification and clonal structure of the European $1108 \quad$ aspen (Populus tremula). Molecular Ecology 14, 2851-2860.

1109 Sverdrup-Thygeson, A., Bendiksen, E., Birkemoe, T. \& Larsson, K. H. 2014. Do conservation 1110 measures in forest work? A comparison of three area-based conservation tools for wood-living 1111 species in boreal forests. Forest Ecology and Management 330, 8-16.

1112 Säynäjoki, R., Packalén, P., Maltamo, M., Vehmas, M., Eerikäinen, K. 2008. Detection of aspens 1113 using high resolution aerial laser scanning data and digital aerial images. Sensors 8, 5037-5054.

1114 Tarasova, V. N., Obabko, R. P., Himelbrant, D. E., Boychuk, M. A., Stepanchikova, I. S., \& 1115 Borovichev, E. A. 2017. Diversity and distribution of epiphytic lichens and bryophytes on aspen 1116 (Populus tremula) in the middle boreal forests of Republic of Karelia (Russia). Folia Cryptogamica $1117 \quad$ Estonica 54 125-141.

1118 Thompson, I.D., Maher, S.C., Rouillard, D.P., Fryxell, J.M., Baker, J.A. 2007. Accuracy of forest 1119 inventory mapping: some implications for boreal forest management. For. Ecol. Manage. 252, $1120 \quad 208-221$.

1121 Tikkanen, O.P., Martikainen, P., Hyvärinen, E., Junninen, K., Kouki, J. 2006. Red-listed boreal forest 1122 species of Finland: associations with forest structure, tree species, and decaying wood. Ann Zool $1123 \quad$ Fenn 43, 373-383.

1124 Torresan, C., Berton, A., Carotenuto, F., Di Gennaro, S.F., Gioli, B., Matese, A., Miglietta, F., 1125 Vagnoli, C., Zaldei, A.,Wallace, L. 2016. Forestry applications of UAVs in Europe: A review. 1126 Internatioanl Journal of Remote Sensing, 1-21. 
Trier, Ø. D., Salberg, A. B., Kermit, M., Rudjord, Ø., Gobakken, T., Næsset, E., \& Aarsten, D. 2018. Tree species classification in Norway from airborne hyperspectral and airborne laser scanning data. European Journal of Remote Sensing 51, 336-351.

1130 Tucker, C. J. 1979. Red and photographic infrared linear combinations for monitoring vegetation.

1131 Remote Sensing of the Environment 8, 127-150.

1132 Tuominen, S., Näsi, R., Honkavaara, E., Balazs, A., Hakala, T., Viljanen, N., Pölönen, I., Saari, H., 1133 Ojanen, H. 2018. Assessment of classifiers and remote sensing features of hyperspectral imagery 1134 and stereo-photogrammetric point clouds for recognition of tree species in a forest area of high 1135 species diversity. Remote Sensing 10, 714.

1136 Ustin, S. L., Gitelson, A. A., Jacquemoud, S., Schaepman, M., Asner, G. P., Gamon, J. A., Zarco1137 Tejada, P. 2009. Retrieval of foliar information about plant pigment systems from high resolution 1138 spectroscopy. Remote Sensing of Environment 113, S67-S77.

1139 Van Bogaert, R., Jonasson, C., De Dapper, M. \& Callaghan, T. V. 2009. Competitive interaction 1140 between aspen and birch moderated by invertebrate and vertebrate herbivores and climate $1141 \quad$ warming. Plant Ecology \& Diversity 2, 221-232.

1142 Van Bogaert, R., Jonasson, C., De Dapper, M., \& Callaghan, T. V. 2010. Range expansion of 1143 thermophilic aspen (Populus tremula L.) in the Swedish Subarctic. Arctic, Antarctic, and Alpine $1144 \quad$ Research 42, 362-375

1145 Vanha-Majamaa, I., Lilja, S., Ryömä, R., Kotiaho, J. S., Laaka-Lindberg, S., Lindberg, H., ... \& 1146 Kuuluvainen, T. 2007. Rehabilitating boreal forest structure and species composition in Finland 1147 through logging, dead wood creation and fire: the EVO experiment. Forest Ecology and $1148 \quad$ Management 250, 77-88.

1149 Vehmas, M., Kouki, Eerikäinen, K. 2009. Long-term spatio-temporal dynamics and historical 1150 continuity of European aspen (Populus tremula L.) stands in the Koli National Park, eastern $1151 \quad$ Finland. Forestry 82, 135-148. 
1152 Vihervaara, P., Mononen, L., Auvinen, A.-P., Virkkala, R., Lü, Y., Pippuri, I., Packalen P., Valbuena, 1153 R. \& Valkama, J. 2015. How to integrate remotely sensed data and biodiversity for ecosystem $1154 \quad$ assessments at landscape scale. Landscape Ecology 30, 501-516.

1155 Wang, R., \& Gamon, J. A. 2019. Remote sensing of terrestrial plant biodiversity. Remote Sensing of $1156 \quad$ Environment 231, 111218.

1157 Whitham, T.G., Bailey, J.K., Schweitzer, J.A., Shuster, S.M., Bangert, R.K., LeRoy, C.J., ... \& 1158 Fischer, D.G. 2006. A framework for community and ecosystem genetics: from genes to 1159 ecosystems. Nature Reviews Genetics 7, 510.

1160 Worrell, R., 1995a. European aspen (Populus tremula L.): a review with particular reference to 1161 Scotland I. Distribution, ecology and genetic variation. Forestry: An International Journal of Forest 1162 Research 68, 93-105.

1163 Worrell, R., 1995b. European aspen (Populus tremula L.): a review with particular reference to 1164 Scotland II. Values, silviculture and utilization. Forestry: An International Journal of Forest $1165 \quad$ Research 68, 231-244.

1166 Wulder, M. A., White, J. C., Goward, S. N., Masek, J. G., Irons, J. R., Herold, M., ... \& Woodcock, 1167 C. E. (2008). Landsat continuity: Issues and opportunities for land cover monitoring. Remote 1168 Sensing of Environment 112, 955-969.

1169 Wulder, M. A., Loveland, T. R., Roy, D. P., Crawford, C. J., Masek, J. G., Woodcock, C. E., ... \& 1170 Dwyer, J. (2019). Current status of Landsat program, science, and applications. Remote Sensing 1171 of Environment 225, 127-147.

1172 Xie, Y., Sha, Z., \& Yu, M. (2008). Remote sensing imagery in vegetation mapping: a review.

$1173 \quad$ Journal of Plant Ecology 1, 9-23.

1174 Zakrisson, C., Ericsson, G. \& Edenius, L. 2007. Effects of browsing on recruitment and mortality of 1175 European aspen (Populus tremula L.). Scandinavian Journal of Forest Research 22, 324-332. 
1176 Zarco-Tejada, P.J., Diaz-Varela, R.; Angileri, V., Loudjani, P. 2014. Tree height quantification using 1177 very high resolution imagery acquired from an unmanned aerial vehicle (UAV) and automatic 3D 1178 photo-reconstruction methods. European Journal of Agronomy 55, 89-99.

1179 Yamasaki, E., Altermatt, F., Cavender-Bares, J., Schuman, M. C., Zuppinger-Dingley, D., Garonna, 1180 I., ... \& Schmid, B. (2017). Genomics meets remote sensing in global change studies: monitoring 1181 and predicting phenology, evolution and biodiversity. Current Opinion in Environmental $1182 \quad$ Sustainability $29,177-186$.

1183 Yang, R. C. 1991. Growth of white spruce following release from aspen competition: 35 year results. 1184 The Forestry Chronicle 67, 706-711.

1185 Yu, X., Hyyppä, J., Litkey, P., Kaartinen, H., Vastaranta, M., \& Holopainen, M. 2017. Single-sensor 1186 solution to tree species classification using multispectral airborne laser scanning. Remote Sensing $11879,108$. 